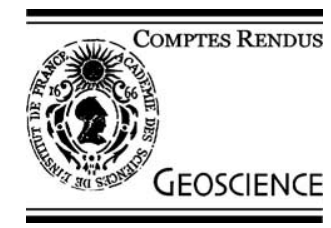

Geodynamics / Géodynamique

\title{
On the ages of flood basalt events
}

\section{Sur l'âge des trapps basaltiques}

\author{
Vincent E. Courtillot ${ }^{\mathrm{a}, *}$, Paul R. Renne ${ }^{\mathrm{b}, \mathrm{c}}$ \\ a Institut de physique du Globe de Paris, 4, place Jussieu, 75252 Paris cedex 05, France \\ $\mathrm{b}$ Berkeley Geochronology Center, Berkeley, CA, USA \\ ${ }^{\mathrm{c}}$ Department of Earth and Planetary Science, University of California, Berkeley, CA, USA \\ Received 18 July 2002; accepted 22 October 2002
}

Written on invitation of the Editorial Board

\begin{abstract}
We review available data constraining the extent, volume, age and duration of all major Phanerozoic continental flood basalts (CFB or traps) and oceanic plateaus (OP), together forming the group of large igneous provinces (LIP), going from the smallest Columbia flood basalts at $\sim 16 \mathrm{Ma}$ to the as yet ill-known remnants of a possible trap at $\sim 360 \mathrm{Ma}$ in eastern Siberia. The 16 traps (CFB and OP) reviewed form a rather unimodal distribution with an initial modal volume of the order of $2.5 \mathrm{Mkm}^{3}$. Most provinces agree with a rather simple first order model in which volcanism may have lasted of the order of $10 \mathrm{Ma}$, often resulting in continental break-up, but where most of the volume was erupted in about $1 \mathrm{Ma}$ or sometimes less. This makes CFBs/OPs (LIPs) major geodynamic events, with fluxes exceeding the total output of present day hot spots and even possibly exceeding over short times the entire crustal production of mid-ocean ridges. The proposed correlation between trap ages and the ages of several geological events, including mass extinctions and oceanic anoxia, is found to have improved steadily as more data have become available, to the point that the list of trap ages may coincide with many major divisions in the geological time scale. The four largest mass extinctions in the last 260 Ma coincide to the best resolution available with four traps, making a causal connection between the two through some form of catastrophic climatic perturbations the most likely hypothesis. The time sequence of LIPs appears to have been random and there is no robust evidence for long time trends in the corresponding crustal production rate over the last $260 \mathrm{Ma}$.
\end{abstract}

() 2003 Académie des sciences/Éditions scientifiques et médicales Elsevier SAS. All rights reserved.

\section{Résumé}

Nous passons en revue l'ensemble des données qui permettent de contraindre l'étendue, le volume, l'âge et la durée de toutes les grandes provinces magmatiques basaltiques (en anglais LIP) d'âge Phanérozoïque, qu'il s'agisse des trapps ou plateaux basaltiques continentaux (en anglais CFB) ou des plateaux océaniques (OP), allant de la plus récente et plus petite (le plateau de Columbia âgé de $\sim 16 \mathrm{Ma}$ ) à l'une des plus anciennes, encore mal connue, située dans l'Est de la Sibérie et sans doute âgée de $\sim 360 \mathrm{Ma}$. Les 16 provinces passées en revue forment une distribution assez unimodale, avec des volumes initiaux de lave de l'ordre de 2,5 $\mathrm{Mkm}^{3}$. La plupart des provinces sont compatibles, au premier ordre, avec un modèle simple selon lequel le volcanisme a pu durer une dizaine de millions d'années et a en général conduit à une déchirure des continents et à l'ouverture d'un nouveau bassin océanique, mais où l'essentiel du volume des laves a été émis en environ 1 million d'années, parfois moins. Ceci fait des trapps (des LIP en général) des événements géodynamiques majeurs, avec des flux de matière ayant dépassé la production totale actuelle des points chauds et même, peut-être, pendant de brefs intervalles, la totalité de la production de croûte 
océanique par les dorsales. La corrélation déjà proposée entre les âges des trapps et ceux des principales extinctions en masse et des événements anoxiques océaniques n'a cessé de s'améliorer au fur et à mesure que des données nouvelles, plus précises, devenaient disponibles, au point que la liste des âges des trapps coïncide sans doute avec la plupart des principales divisions de l'échelle des temps géologiques. Les quatre plus grandes extinctions des derniers 260 Ma coïncident, avec la précision la meilleure aujourd'hui disponible, avec quatre trapps, faisant d'une interprétation causale de cette coïncidence, par le biais de perturbations climatiques catastrophiques, l'hypothèse la plus probable. La séquence temporelle des LIP semble aléatoire, et il n'y a pas d'indication solide de fluctuations systématiques à long terme du taux de production correspondante de croûte au cours des 260 derniers millions d'années.

(C) 2003 Académie des sciences/Éditions scientifiques et médicales Elsevier SAS. Tous droits réservés.

Keywords: Flood basalts; Large igneous provinces (LIP); Geological ages; Geochronology; Mass extinctions; Oceanic anoxia events; Correlation

Mots-clés : Plateaux de basaltes; Provinces océaniques ; Grandes provinces magmatiques (LIP); Âges géologiques ; Géochronologie ; Extinctions en masse ; Événements d'anoxie océanique ; Corrélation

\section{Introduction}

Flood basalts are truly gigantic volcanic constructs, consisting primarily of tholeiitic basalts, which have attracted the attention of geologists for well over a century. However, continental flood basalts (CFB) were generally not given great attention until it was realized in the mid-eighties, largely thanks to progress in magnetostratigraphy and geochronological techniques, that they could have been emplaced in a comparatively short time, implying geodynamically very significant mass fluxes, comparable to those involved in the buildup of oceanic crust at mid-ocean ridges. Another feature of flood basalts is that they are relatively rare occurrences at the Earth's surface. Only a dozen flood basalts (including submarine oceanic plateaus, which are equivalent to flood basalts when emplacement occurred on oceanic rather than continental lithosphere) have been identified over the last 300 million years, that is one event per 20 to 30 million years (although there is no periodicity in this time series). Together, flood basalts and suboceanic plateaus are often termed large igneous provinces (LIP). The 16-item list given in Table 1 could be incomplete, since CFBs (and oceanic plateaus or OPs) could have been subducted or consumed during continental collision (we will see one example of the latter in Asia, and possibly of the former in the Pacific). But it seems unlikely that many others would remain hidden be-

\footnotetext{
* Correspondence and reprints.

E-mail address: courtil@ipgp.jussieu.fr (V.E. Courtillot).
}

neath sediments in either oceanic or continental surroundings. In a recent review, Eldholm and Coffin [48] list a number of useful parameters for what they call transient LIPs. This includes most of those listed in Table 1, plus 14 other oceanic plateaus, ocean basin flood basalts and volcanic margins that are often far less well known and which we believe may be different geodynamical features (see below and [39]). Very significant work on most CFBs and LIPs (though not all yet) in the last 15 years has shown that a typical province covers a surface of the order of 1 million $\mathrm{km}^{2}$, with an extruded volume of the order of 1 million $\mathrm{km}^{3}$ (see, e.g., reviews in [37,112,189]). Eldholm and Coffin [48] list LIP areas (sometimes present, sometimes assumed original values) and volumes (sometimes extruded components, sometimes subducted, sometimes all supracrustal and infracrustal components) that range respectively from 0.1 to $3.1 \mathrm{Mkm}^{2}$, and from 0.5 to $44.4 \mathrm{Mkm}^{3}$. As a result, the Siberian traps are listed with a volume of $1.2 \mathrm{Mkm}^{3}$ and the Ontong-Java plateau with $44.4 \mathrm{Mkm}^{3}$. But, in the former case, only the extrusives emplaced above the continental crust and lithosphere are taken into account (with a mean thickness of $500 \mathrm{~m}$ ), whereas in the latter the entire suite of extrusive cover, middle crustal components and lower crustal body revealed by gravity and seismic exploration are included. This implies that the volumes cannot be compared and do not reflect the respective geodynamical significances of these bodies. In the case of continental flood basalts, much of the original volume may have disappeared since emplacement because of various forms of erosion. Dessert 
Table 1

List of Large Igneous Provinces (or LIPs), comprising continental flood basalts (CFB) and oceanic plateaus (OP), sometimes with associated volcanic margins (VM). Mean ages and age ranges are in Ma; $\mathbf{S}$ are LIP surfaces in $\mathrm{Mkm}^{2}$ (either present, estimated by Eldholm and Coffin [48], or original as estimated in this paper); $\mathbf{V}$ are corresponding LIP volumes in $\mathrm{Mkm}^{3} ; \mathbf{E E}$ and $\mathbf{O A E}$ are mass extinction events and/or oceanic anoxic events (the latter after Wignall [190]), i.e. major breaks in the geological time scale, with their ages in Ma. Values are discussed in the paper with some relevant references

Tableau 1

Liste des grandes provinces magmatiques (en anglais Large Igneous Provinces ou LIP), comprenant les plateaux basaltiques continentaux ou trapps (en anglais CFB) et les plateaux océaniques (en anglais $\mathbf{O P}$ ), parfois avec leurs marges volcaniques associées (en anglais $\mathbf{V M}$ ). Les âges moyens et les intervalles d'âges sont en millions d'années (Ma). $\mathbf{S}$ est la surface des LIP en millions de kilomètres carrés (soit actuelle, évaluée par Eldholm et Coffin [48], soit à l'origine, évaluée dans cet article). V est le volume correspondant des LIP en millions de kilomètres cubes. EE et $\mathbf{O A E}$ sont respectivement les événements d'extinction en masse et les événements anoxiques océaniques (ces derniers d'après Wignall [190]), correspondant aux grandes coupures dans l'échelle des temps géologiques, avec leurs âges en Ma. Les valeurs sont discutées dans l'article et quelques références utiles sont données

\begin{tabular}{|c|c|c|c|c|c|c|c|c|c|c|c|}
\hline LIP & Cat. & Mean age & Age range & $\mathbf{S}$ (pres) & $\mathbf{S}(\mathrm{EC} 00)$ & $\mathbf{S}$ (orig) & $\mathbf{V}$ (pres) & $\mathbf{V}(\mathrm{EC} 00)$ & $\mathbf{V}$ (orig) & EE or OAE & Age \\
\hline Viluy traps & CFB? & in prog. & 377-350 (strat.) & & & & & & & end Frasnian? & 360 \\
\hline Emeishan traps & CFB & $259 \pm 3$ & & $>0.5$ & 0.3 & 2 to 5 & & & $>1$ & end Guadalupian & 258 \\
\hline Siberian traps & CFB & 250 & 249-251 & 0.4 & 2.5 (orig) & $>4$ & & $1.2(\mathrm{ext})$ & $>3$ & end Permian (OAE) & 250 \\
\hline $\begin{array}{l}\text { Central Atlantic Magmatic } \\
\text { Province }\end{array}$ & $\mathrm{CFB} / \mathrm{VM}$ & 201 & $200-202(<1)$ & & 0.1 & $>7$ & & 0.7 (all) & $>2$ & end Triassic (OAE?) & 200 \\
\hline Karoo and Ferrar traps & CFB & 183 & $182-184$ & & 3.1 & & & $1.5(\mathrm{ext})$ & $>2.5$ & end Pliensbachian (OAE) & 184 \\
\hline Parana and Etendeka traps & CFB & 133 & $132-134(80 \%)$ & 1.5 & 2.3 (orig) & $>2$ & & 21 (all) & $>2.3$ & end Valanginian? & 132 \\
\hline Rajmahal traps/Kerguelen plateau & $\mathrm{CFB} / \mathrm{OP} ?$ & 118 & $\ll 109-119$ & & & & & 6 (all) & & end Early Aptian? & 117 \\
\hline Ontong-Java plateau 1 & OP & 122 & & & & & & & & end Early Aptian? (OAE) & 117 \\
\hline Ontong-Java plateau 2 & OP & 90 & & 2 & 1.9 & & & 44.4 (all) & $6 ?$ (ext) & $\begin{array}{l}\text { end Cenomanian? } \\
\text { Turonian? (OAE) }\end{array}$ & $93 / 89$ \\
\hline Caribbean plateau & $\mathrm{OP}$ & 89 & $89-90$ & & 1.1 & & 4 & 4.5 (all) & 4 & $\begin{array}{l}\text { end Cenomanian? } \\
\text { Turonian? (OAE) }\end{array}$ & $93 / 89$ \\
\hline Madagascar traps & CFB/VM? & 88 & $86-90$ & & (1.6?) & & & 4.4 (all) & & end Cenomanian? (OAE) & 93/89 \\
\hline Deccan traps & CFB & 65.5 & $65-66(>80 \%)$ & 0.5 & 1.8 (orig) & $>1$ & 1 & 8.6 (all?) & 2 to 4 & end Cretaceous & 65 \\
\hline $\begin{array}{l}\text { North Atlantic Tertiary } \\
\text { Volc. Prov. } 1\end{array}$ & CFB & 61 & $<59-62$ & & & & & & 2 & end E Paleocene(OAE) & 60 \\
\hline $\begin{array}{l}\text { North Atlantic Tertiary } \\
\text { Volc. Prov. } 2\end{array}$ & CFB/VM? & 56 & $<54-57$ & & 1.2 & & & 9.9 (all) & $>2$ & end Paleocene (LPTM) & 55 \\
\hline Ethiopian and Yemen traps & CFB & 30 & $29.5-31(80 \%)$ & 0.7 & 0.8 (orig) & & 0.35 & $0.5(\mathrm{ext})$ & 1.2 & Oi2 event & 30 \\
\hline Columbia River Flood Basalts & CFB & 16 & $15.3-16.6(95 \%)$ & & 0.2 & & 0.17 & 1.3 (all) & 0.2 & end Early Miocene? & 16 \\
\hline
\end{tabular}


et al. [41] argue that much of the $\mathrm{CO}_{2}$ emitted at the time of trap emplacement must have reacted with the basalts, possibly removing as much as half of the total original volume in only a few million years. Nick Arndt (pers. comm., 2002) points out that part of the altered trap sequences may remain in situ, depending on climate in particular. In any case, present remaining volumes of $\mathrm{CFBs}$ must often underestimate (sometimes by a large amount) the original volumes. On the other hand, true submarine traps or oceanic plateaus that were erupted on oceanic crust and under water are likely to have had larger extruded volumes and less erosion. Also the mid-crustal and lower crustal bodies should not be included when comparing their volumes with those of CFBs (or the midcrustal and lower crustal bodies should be included for the CFBs, but they are generally not (yet) imaged well enough). Indeed, a plume rising below shallower oceanic lithosphere will melt more and produce a larger volume of magma than one arriving beneath thicker continental lithosphere. For this reason, the extruded parts of oceanic LIPs are expected to be bigger than those of continental CFBs, and again the lower crustal part should not be included in the comparison. We have attempted to take this into account in Table 1, where it is found that the original volumes of supracrustal, extruded basalts of CFBs and OPs are actually quite comparable. Except for the tiny Columbia River Flood Basalt, most original trap volumes are estimated to have been larger than $2 \mathrm{Mkm}^{3}$ and possibly up to 4 . In contrast, the Ontong-Java plateau extruded volume could be of the order of $6 \mathrm{Mkm}^{3}$, therefore not significantly different (and certainly not an order of magnitude larger). The distribution of original extruded LIP volumes is still plagued with uncertainties, but appears rather unimodal, with a mode likely above $2 \mathrm{Mkm}^{3}$. A consequence of this analysis is that many previous estimates of time evolution of crustal production rates (e.g., [48]) are biased by this unbalance between CFB extruded volumes and OP total crustal volumes, and that the rate based on LIPs alone may well be rather constant in time, with no strong evidence for a peak at $120 \mathrm{Ma}$ (the age of the Ontong-Java plateau that biases all), nor for a decrease up to the Present.

Most geochronology studies, to be reviewed briefly in this paper, point to a typical duration of 1 million years for the bulk of trap eruption. Therefore, the typical flux is of the order of or larger than $2 \mathrm{~km}^{3} \mathrm{yr}^{-1}$, and could have been of an order of magnitude higher if shorter durations and/or larger volumes apply (which is probable in at least a few cases). CFBs and LIPs are therefore very important geodynamic features, generally unrelated to classical plate dynamics, which may hold the key to important aspects of mantle convection. For instance, their depth and mechanism of origin, link to hot spots, kinematics relative to the transition zone and lower mantle are all subjects of active debate. Moreover, CFBs appear to be closely connected in space and time with major episodes of continental breakup and opening of ocean basins, and it has even been suggested that the geography of the major ocean basins, when untouched by later subduction or collision, could reflect the past distribution of locations where deep mantle plumes first erupted as flood basalts (e.g., [37]). Finally, after early proposals by Vogt [185] and Morgan [123], the idea that trap eruption times coincide with major mass extinctions has gained support, as more numerous and accurate ages for both CFBs and extinctions became available [31,32]. Other CFBs have been associated with major episodes of oceanic anoxia (OAE), and/or with more minor extinction and bioclimatic events (see [190]). A typical trap comprises hundreds of individual flows, many of which exceed $100 \mathrm{~km}^{3}$ in volume, and some of which can reach thousands of cubic kilometers, exceeding the size of the largest historical basaltic flows by more than two orders of magnitude. Regardless of whether traps and extinctions do correlate, it is interesting to address the problem of how the hydrosphere and atmosphere can be affected by the gases and aerosols injected during the eruption of hundreds of such flows over geologically short time intervals. The detailed time history of individual eruption events is still beyond the reach of our dating methods, but paleoclimate modeling may soon reach a stage where such events can be quantitatively analyzed.

The most important geochronologic constraints on flood basalts today are provided by the ${ }^{40} \mathrm{Ar} /{ }^{39} \mathrm{Ar}$ and K/Ar methods, whose precision can be better than $0.1 \%$, but whose accuracy is presently limited to about $2 \%$ due to systematic errors [120]. The most reliable ${ }^{40} \mathrm{Ar} /{ }^{39} \mathrm{Ar}$ ages on flood basalts per se are obtained from plagioclase separates, whose $\mathrm{K}$ content is generally sufficient to produce high-quality data. Application of the intrinsically more accurate $\mathrm{U}-\mathrm{Pb}$ method is mainly restricted to the relatively 
rare zircon- or baddelyite-bearing silicic flows or associated intrusions. Other radioisotopic methods such as Re/Os (e.g., Allègre et al. [1] and Rb/Sr [6, 186]) show promise despite still scattered isochrons, a feature which must be resolved before these methods are considered capable of contributing appreciably to the chronology of flood volcanism. Comparison of ages from different radioisotopic dating methods must bear in mind the systematic errors intrinsic to each, as failure to do so can introduce spurious apparent age dispersion, and it must be considered that few methods are more accurate than about $1 \%$ of the age (e.g., [13]).

Evidence that traps have some bearing on the dynamics of possibly all of the Earth's envelopes, from the core to the atmosphere, critically relies on the amount and quality of ages obtained from flood basalt samples. We refer readers to the recent review by Wignall [190] who focuses on paleontological observations of extinctions and anoxia events, and on chemical and climatological concepts that could allow us to argue whether a causal connection is possible. In the present paper, we focus on an update on the geochronological constraints that have become available in the last decade, and to their consequences on a number of the problems outlined in this introduction. Out of many possible presentations, we have selected to review data from CFBs and OPs known to us (Table 1), going from the youngest (the 15-Ma-old Columbia flood basalts) for which preservation is expected to be better, to the older, such as the 258-Maold Emeishan traps, or possibly the 360-Ma-old traps in Siberia.

\section{The Columbia-Snake River flood basalts}

The Columbia River basalts are at the same time the youngest but also the smallest CFB. They are so small $\left(0.17 \mathrm{Mkm}^{3} ;[177]\right)$ that they are a distant outlier of the general distribution. It can even be questioned whether they should be included in the list. Although they do span some time between possibly 17 and $6 \mathrm{Ma}$, almost $95 \%$ of the total volume was erupted between 16.6 and 15.3 Ma [19]. The eruptive history is sketched in Wignall [190] (Fig. 3). Of course, remaining errors and undetected effects of alteration can be responsible for part of the scatter, but the general outline appears to be robust. Lange [103] shows that the original volatile concentrations $\left(\mathrm{H}_{2} \mathrm{O}+\mathrm{CO}_{2}\right)$ may have reached the exceptionally high value of $4 \%$. Lange proposes that this explains large individual flow volumes and the ability of the dense Fe-rich lava to erupt through as much as $20 \mathrm{~km}$ of continental crust. She notes that this is 20 times the value generally based on Leavitt [105] and used for instance by Caldeira and Rampino [18] to estimate $\mathrm{CO}_{2}$ emissions from flood basalts. Coffin and Eldholm [25] suggest a possible link to a mid-Miocene extinction, but Wignall [190] notes that this is not a major event in the compilation of Raup and Sepkoski [146]. However interesting, the Columbia River FB seems to be a volumetrically and geodynamically minor event compared to all other CFBs.

\section{The Ethiopian and Yemen traps}

Though apparently the youngest and possibly the best preserved of the major traps, the Ethiopian lavas had not been well dated until recently. The Ethiopian traps presently cover about $0.7 \mathrm{Mkm}^{2}$ and their volume amounts to $0.35 \mathrm{Mkm}^{3}$ according to Mohr and Zanettin [121]. Because the traps actually comprise the now severed extension of the Yemen traps [118], because of significant removal at the time of continental breakup and opening of the Red Sea and Gulf of Aden, and because of subsequent erosion and alteration, their original volume is estimated to have reached at least $1.2 \mathrm{Mkm}^{3}$ [158]. Based on a geochronological and magnetostratigraphic study of the $\sim 2000$-m-thick Lima-Limo section in the northern part of the Ethiopian traps, Hofmann et al. [77] concluded that the traps formed in 1 to 2 million years $30 \mathrm{Ma}$ ago. Four plateau ages, two sanidine singlegrain determinations and one isochron age range from 28.6 to $30.0 \mathrm{Ma}$, with $95 \%$ uncertainties of $0.3 \mathrm{Ma}$. A histogram of ten age determinations (mostly ${ }^{40} \mathrm{Ar} /{ }^{39} \mathrm{Ar}$ plateau ages) indeed shows a single sharp peak at $30 \mathrm{Ma}$ with a half-width of 1.5 Ma. Baker et al. [9] found similar ages in Yemen, spanning from 29.2 to $30.9 \mathrm{Ma}$. Only two magnetic reversals were found in the Lima-Limo section, which was identified by Hofmann et al. [77] as spanning from chron C11r to C10r. Analyses from additional samples led Rochette et al. [158] to propose that only two correlations with the geomagnetic polarity time scale (GPTS) were possible: 
a 'long' one, lasting 1.9 Ma from chron $\mathrm{C} 11 \mathrm{r}$ to $\mathrm{C} 10 \mathrm{r}$, and a 'short' one, lasting $0.8 \mathrm{Ma}$ from $\mathrm{C} 11 \mathrm{r}$ to $\mathrm{C} 11 \mathrm{n}$ 1r. Ukstins et al. [181] have very recently published a set of sixteen new ${ }^{40} \mathrm{Ar} /{ }^{39} \mathrm{Ar}$ dates from five sections on the eastern margin of the Ethiopian plateau, and have compiled 96 ages from Ethiopia and Yemen (recalculated to the Fish Canyon sanidine standard at 28.02 $\mathrm{Ma}$ as in [153]). The data distribution well reflects the short, major pulse of flood basalt volcanism and a long, sporadic history of subsequent volcanism linked to breakup. The data clearly show a gap at $\sim 26 \mathrm{Ma}$ and a major (Gaussian-like) peak at $30 \mathrm{Ma}$ with a width at half height of $1.5 \mathrm{Ma}$. Though Ukstins et al. [181] imply that volcanism was continuous between 29 and $26 \mathrm{Ma}$, this is not borne out on a regional scale. Coulié et al. [29] analyzed basaltic and silicic samples, from both the Yemen and Ethiopian traps, using both the Cassignol-Gillot K/Ar method and the ${ }^{40} \mathrm{Ar} /{ }^{39} \mathrm{Ar}$ method (see also [28]). Interlaboratory biases and discrepancies in the ages of standards were thus largely eliminated and the authors concluded that ages by both methods were concordant, and that onset of volcanism was coeval over the whole province at $30.6 \pm 0.4 \mathrm{Ma}$ and $30.2 \pm 0.4 \mathrm{Ma}$, respectively, in Ethiopia and Yemen. Thanks to the larger K-content of the silicic samples, the authors were able to show that most of the lava pile erupted in less than $1 \mathrm{Ma}$, though volumetrically smaller lavas were dated at $26 \mathrm{Ma}$ and younger ages.

Using a technique based on magnetic susceptibility, Touchard [179] identified four tephra layers in cores from the Indian Ocean (leg 115), Arabian Sea (leg 23, site 220) and South Atlantic (leg 73, site 522). They were able to show that these tephra are the chemical equivalents of the rhyolitic lavas in the upper Wegel Tena section. Using a paleoclimatic model (e.g., [54]), Touchard evaluated the extent, volume, flux and dynamic wind transport of the tephra, and most importantly was able to tie in the events to the biostratigraphic time scale. His work and that of Coulié et al. [29] confirm that volcanism lasted from chron $\mathrm{C} 11 \mathrm{r}$ to $\mathrm{C} 11 \mathrm{n}-1 \mathrm{r}$, with an upper bound of $800 \mathrm{kyr}$ on total duration of the main basaltic and rhyolitic phases, and of about $100 \mathrm{kyr}$ for the terminal bimodal (basaltic and rhyolitic) phase, which amounts to $800 \mathrm{~m}$, i.e. $40 \%$ of the total plateau thickness. The resolution of the biostratigraphic correlation, brevity of reversed subchron $\mathrm{C} 11 \mathrm{n}-1 \mathrm{r}$ and small uncertainty on age determinations have led Touchard et al. [180] to propose that it could be used as a new tie-point of the GPTS at 30.1 Ma. On the other hand, the welldefined age of the $\mathrm{C} 11 \mathrm{n}-2 \mathrm{n}$ to $\mathrm{C} 11 \mathrm{n}-1 \mathrm{r}$ reversal, which is bracketed by four K-feldspar age spectra, has led Coulié et al. [29] to propose an age of $29.75 \pm 0.10 \mathrm{Ma}$ for this $\mathrm{N}$ to $\mathrm{R}$ tie-point. When uncertainties on age standards are taken into account, both ages are actually defined with an uncertainty no less than $0.3 \mathrm{Ma}$ and are therefore not yet distinguishable.

It is particularly significant that the traps do not coincide with the Eocene/Oligocene boundary at 33.7 Ma, which may not be the most significant extinction or climatic event in the Cenozoic as was once believed. Iridium anomalies have been observed in Italy by Montanari et al. [122] and three widely separated impact craters are dated at about 35 to $36 \mathrm{Ma}$ (e.g., [109]), which does correlate with a minor extinction in warm water taxa, but occurs about 1.5-2.5 Ma before the E/O boundary. Six important cooling events are now identified between 35 and $26 \mathrm{Ma}$ through a combination of eustatic sea-level changes [71,99], and $\delta^{18} \mathrm{O}$ isotopic ratio (e.g., [119,193]): they are called Oi1 (at the E/O boundary), Oi1a, Oi1b, Oi2, Oi2a, and Oi2b. Zachos et al. [194] display the $\delta^{18} \mathrm{O}$ isotopic ratio from $65 \mathrm{Ma}$ to the Present. A major, sharp $\delta^{18} \mathrm{O}$ positive anomaly and therefore global cooling occurs at the Eocene/Oligocene boundary (Oi1) at $33.7 \pm 0.5 \mathrm{Ma}$. But the ratio remains small for $8 \mathrm{Ma}$. Using an earlier version of the $\delta^{18} \mathrm{O}$ curve [119], Prothero [140] finds evidence for a "much bigger and more protracted glacial event, or events starting about $30 \mathrm{Ma}$ ago" (Oi2), i.e. at the time of peak trap eruption. Prothero [140] actually considered the Eocene/Oligocene boundary a 'non-event' from a paleontological perspective. Following these observations, Hofmann et al. [77] (see also Rochette et al. [158]) concluded that the traps coincided in time with (i) the largest sea-level drop in the Cenozoic [71], (ii) a major glaciation in Antarctica, and (iii) a minimum in diversity of land mammals. Touchard et al. [180] and Ayalew et al. [6] emphasized the potential climatic impact of the silicic phases. More importantly, they demonstrated that the traps and the Oi2 climatic cooling event were indeed coeval, with the key role being attributed to $\mathrm{SO}_{2}$ emissions.

In a recent study, Kieffer et al. [95] noted that shield volcanoes overlying the traps had chemistries simi- 
lar to the underlying flood basalts, but that the chemical make-up changed from one sub-province to the other. Shield volcano ages were $30 \mathrm{Ma}$ in one case, but $23 \mathrm{Ma}$ in two other cases. They concluded that volcanism was complex and protracted, in relation with a heterogeneous plume head and underlying mantle. We point out that in order to properly identify the dynamic importance of flood basalt volcanism, the time history of volcanic flux must be determined in a quantitative way. In Ethiopia and Yemen, the sections that yielded coeval $30 \mathrm{Ma}$ ages are by far the largest and thickest (more than $75 \%$ of total volume). Only more modest volumes and episodic volcanism occurred from 29 to $23 \mathrm{Ma}$. Kieffer et al. [95] estimate that the volumes of post-30-Ma shield volcanoes could be from 5 up to $25 \%$ of the volume of the traps. The younger events can be linked to the major phase of continental breakup that marked the onset of successful rifting in the Red Sea and Gulf of Aden [37]. It should be recalled that the Ethiopian traps are the youngest, best preserved, large CFB and that features such as overlying shield volcanoes might not have been preserved in other provinces. The characteristic bimodal volcanism, with 5 to $20 \%$ of the volume of the traps being siliceous (rhyolitic), is found in the Paraná and Ethiopian traps, but not in the Deccan or Madagascar, whereas in Siberia trachytic volcanism occurs [95]. Despite these differences, features of the Ethiopian traps such as volume, duration, climatic impact, and relation to continental breakup are similar to those of other traps. They are to our knowledge one of several cases (other being the Deccan, CAMP and Siberian traps, see below) where synchroneity of a major bioclimatic event and trap emission has been demonstrated.

\section{The Brito-Arctic province}

The Brito-Arctic province (also known as the North Atlantic Tertiary Volcanic Province or NATVP) may be one of the most studied CFBs, in relation to early models of plume generation, plume-rift interaction and opening of the North Atlantic Ocean. Recent dating and seismic work has provided large amounts of data that constrain the time-history of magmatic flux better than in many other provinces. Two main pulses of basaltic volcanism occurred. The first one, around 61.0 Ma, amounting to some $2 \mathrm{Mkm}^{3}$ in total volume, developed in western Greenland, southeastern Greenland (and possibly between the two below the ice), and northwest Britain (e.g., [43,68,104,172,173]). The second one (even larger) corresponds to breakup at $56 \mathrm{Ma}$ and is found in both eastern Greenland and the Faroes, along part of the then nascent North Atlantic margin, but also in Baffin Bay west of Greenland [57,113]. The former shares the characteristics of many other provinces in having recorded few reversals and being confined in time to a total duration of the order of 1-2 Ma (note however that the volume estimate is subject to the presence of flood basalts below the ice sheet connecting the eastern- and western-coast outcrops, which is debated; Laurent Geoffroy, pers. comm., 2002). The high-velocity crustal 'seaward dipping reflectors series' (SDRS) discovered in seismic lines (see [75]), with a total volume (extruded part) in excess of $2 \mathrm{Mkm}^{3}$, correspond to mainly subaerially erupted basalts (with minor trachyte dykes); their volume (close to $10 \mathrm{Mkm}^{3}$ in [48]) is well constrained, but corresponds to the deeper, mid- and lower crustal components that cannot be included in volume estimates for pre-rift CFBs (see introduction and Table 1). Tegner et al. [176] dated mafic intrusions by ${ }^{40} \mathrm{Ar} /{ }^{39} \mathrm{Ar}$ along the eastern-Greenland rifted margin. They find that tholeiitic magmatism occurred in three discrete pulses at $\sim 62-59 \mathrm{Ma}, 57-54 \mathrm{Ma}$, and 50-47 Ma, related to melting episodes triggered respectively by plume impact, continental breakup, and passage of the plume axis. Holbrook et al. [79] determined the time evolution of magmatic productivity since the onset of breakup (i.e. the 56 to 55.5-Ma-old (C25n) continentocean boundary - COB), which decreases drastically by a factor in excess of 3 in less than $10 \mathrm{Ma}$. This led them to infer a plume-impact model for Greenland trap generation, with a $600-\mathrm{km}$ diameter at COB time and a rather modest $125^{\circ} \mathrm{C}$ mantle thermal anomaly. Results from Mull and Skye [22] indicate a slight broadening of this age range, into $\mathrm{C} 26 \mathrm{r}$.

Courtillot et al. [37] noted that double pulses, such as the 61-Ma CFB and 56-Ma SDR events, could be found in other LIPs. In the case of the Afar plume, for instance, the 30-Ma Ethiopian traps could correspond to the Greenland traps, and the 3-Ma-to-Present traplike stratoid series to the SDRS. The former would have erupted entirely as a subaerial event, whereas the latter (which are linked with significant extension) could in part be subaquatic, implying significant dif- 
ferences in potential climatic impact. The synthesis of mean global temperatures since the K/T boundary of Zachos et al. [194], which is based on $\delta^{18} \mathrm{O}$ data, does not show a consistent correlation with either one of the Brito-Arctic events. The older corresponds to a cold minimum, whereas the younger occurs at the time of the sharp, warm event of less than 200-kyr duration [128], termed the Late Paleocene Thermal Maximum (LPTM). In a recent, controversial publication, Jolley et al. [87] argue that $\mathrm{U}-\mathrm{Pb}$ and ${ }^{40} \mathrm{Ar} /{ }^{39} \mathrm{Ar}$ ages of Brito-Arctic lavas, immediately overlying sedimentary strata in which the LPTM was recorded, extend from 57.5 to $60.5 \mathrm{Ma}$. These authors conclude that the Paleogene time scale could be in error by up to $5 \mathrm{Ma}$ and that the LPTM, if redated at $\sim 60 \mathrm{Ma}$, could correspond to the main continental and subaerial phase of Greenland-Britain volcanism, due to the release of ocean-floor methane hydrates [42]. However, Aubry et al. [5] reject any potential miscalibration of the time scale, and believe that Jolley et al.'s conclusions are based on "selective use and misinterpretation of geochronologic data and undue reliance on imprecise and unsubstantiated palynologic evidence".

\section{The Deccan traps}

The Deccan traps may be one of the earliest CFB provinces to have been studied with the modern tools of magnetostratigraphy and radioisotopic geochronology. After early suggestions of a possible correlation of the traps with the K/T mass extinction by Vogt [185], Courtillot et al. [34,35] pointed out that the joint finding of (i) only three chrons in the lava pile, with the central largest portion being reversely magnetized, (ii) the presence of a characteristic Maastrichtian fossil fish tooth found in the infratrappean sediments, and (iii), then available (if moderately reliable), K/Ar ages close to $66 \mathrm{Ma}$ indicated that the bulk of the traps was most likely emplaced over chrons C30n, C29r and $\mathrm{C} 29 \mathrm{n}$, in less than one million years, straddling the Cretaceous-Tertiary (K/T) boundary. The current trap surface is of the order of $0.5 \mathrm{Mkm}^{2}$, but much of it has been removed by erosion, continental breakup and rifting away of the Seychelles plateau. Most authors quote an original volume of the order of $2 \mathrm{Mkm}^{3}$. The recent work by Dessert et al. [41] outlines the importance of early chemical erosion of the traps linked to increased atmospheric $\mathrm{CO}_{2}$ content and shows that this is probably an underestimate. Duncan and Pyle [45] and Courtillot et al. [36] published ${ }^{40} \mathrm{Ar} /{ }^{39} \mathrm{Ar}$ plateau ages (from both across the trap horizontal surface and vertical section) that further strengthened the age estimate and brief duration of the bulk of trap volcanism. Further ages have been published since, and ensuing debate has continued over the last decade. Baksi and Farrar [10] presented ages ranging from 67.6 to $64.5 \mathrm{Ma}$, and Venkatesan et al. [183] argued that volcanism actually started massively at $67 \mathrm{Ma}$ in chron C31r, that is at least $1 \mathrm{Ma}$ prior to the K/T boundary. Féraud and Courtillot [53] challenged these results. Allègre et al. [1] assumed a brief time interval of volcanism over $1500 \mathrm{~m}$ of stratigraphic section and $800 \mathrm{~km}$ in lateral extent using the new Re-Os technique and obtained a well constrained mean age value. All data agreed with an age of $65.6 \pm 0.3 \mathrm{Ma}$, and ${ }^{187} \mathrm{Os} /{ }^{188} \mathrm{Os}$ initial ratio showed a mantle source with minor metasomatism and crustal contamination. Hofmann et al. [78] resampled the traps and found virtually undistinguishable ${ }^{40} \mathrm{Ar} /{ }^{39} \mathrm{Ar}$ plateau ages of $65.4 \pm 0.7 \mathrm{Ma}$ for five flows extending over a few hundred meters of section near the base of the lava pile, and 65.2 $\pm 0.7 \mathrm{Ma}$ for a dyke cutting across the Poladpur formation, which immediately underlies the topmost Mahabaleshwar formation. This implies that at least $1800 \mathrm{~m}$ out of the full 2500$\mathrm{m}$-thick section erupted close to $65.5 \mathrm{Ma}$ in much less than $1 \mathrm{Ma}$ (the best constraint on duration still coming from magnetostratigraphy). Interestingly, and as has been found in other cases (such as the Ethiopian traps), it was found that age histograms became narrower as new, better data were acquired and as more stringent selection criteria were applied. For instance, Hofmann et al. [78] found that when going from an original data base of 33 plateau ages to 24 'A-quality' results, then to a restriction to 13 plateau ages on mineral separates, the half-width of the main histogram peak was reduced from $\sim 4$ to $\sim 1 \mathrm{Ma}$. Rao and Lakshmi [144] confirmed that most of a 338-m-long core from a borehole near the southeastern boundary of the traps had reversed magnetization and was likely coeval with the C29r age of the bulk of the Mahabaleshwar sections. Even farther from the main sections of the western Ghats, lavas of the Rajahmundry Traps on the eastern coast of India, chemically identical to the Poladpur and Ambenali formations, have recently [96] been dated by ${ }^{40} \mathrm{Ar} /{ }^{39} \mathrm{Ar}$ as being indistinguish- 
able from these formations. Thus, the original extent of Deccan magmatism is even significantly larger than commonly believed.

Bhandari et al. [14] reported the discovery of iridium in sediments intercalated between flows in the (ill-mapped) Anjar area (Kutch Province) in the northwest of the trap province. Further joint work by Courtillot et al. [38] and Shukla et al. [164] has provided more, if sometimes contradictory, results on this remote thin section of seven traps flows. Both teams confirm the rough location and existence of the Ir anomaly, though intensities are a bit different. Both also agree on the fact that flows below the Ir bearing layers have normal magnetic polarity, and those above have reversed polarity, except for a normal layer that may either correspond to a later dyke or have been subsequently remagnetized. Both teams further agree on the ages of three overlying flows at $65 \mathrm{Ma}$ in chron $\mathrm{C} 29 \mathrm{r}$, and assign the same age to the underlying intertrappean level. However, there are significant discrepancies in some ${ }^{40} \mathrm{Ar} /{ }^{39} \mathrm{Ar}$ ages. Shukla et al. [164] choose to average discrepant ages, even if their uncertainties did not overlap, whereas Courtillot et al. [38] (see also [77]) explain why they believe their ages more reliable. Courtillot et al. see the three underlying flows as being roughly coeval at $66.5 \mathrm{Ma}$ with chron C30n (consistent with the 3chron model defended since 1986), whereas Shukla et al. (based on [184]) propose ages ranging from ca 69 to $65 \mathrm{Ma}$ for the same flows. These authors therefore argue for prolonged volcanism, starting in chron C31n.

Despite some disparate conclusions, these studies have a common important consequence that the Ir bearing sediments, if related to the Chixculub crater impact as generally accepted, indicate that Deccan volcanism began prior to impact and straddled it in time, excluding the sometimes invoked possibility of a causal connection between the two. On the other hand, a minority view is held by Hansen et al. [70] that iridium is not unique to the $\mathrm{K} / \mathrm{T}$ and could be derived from rhyolitic bentonites in Anjar. These authors believe that the Ir-rich sediments contain non-reworked dinosaur eggshell fragments [7,8], and predate the K/T boundary (i.e. are located within the Maastrichtian part of reversed chron C29r). The results of Venkatesan et al. [184] and a number of others suggest that Deccan volcanism started at least $67 \mathrm{Ma}$ ago, and possibly $69 \mathrm{Ma}$ ago, and ended only $61 \mathrm{Ma}$ ago, therefore lasting up to $8 \mathrm{Ma}$. Although we (together with [38, $53,77,78]$ ) would argue that many older and younger ages are based on lower quality, disturbed spectra as well as whole rock samples that may have been affected by alteration and recoil, the important question is to reconstruct the flux (or volume) history of volcanism. For instance, Sheth et al. [163] find an age between 60 and $62 \mathrm{Ma}$ on trachyte dykes (not flows) from near the coast and flexure marking the edge of continental breakup between India and the Seychelles. It is not surprising that a tail (and more) of volcanism should mark the later breakup phase following trap emplacement [34,35,37], as has been seen to be the case with much larger volumes for the Ethiopian and Brito-Arctic traps. Very recently, Mahoney et al. [114] have identified volumetrically minor but geologically significant volcanic rocks in the Tethyan suture, which suggest that the Réunion hot spot was active at $73 \mathrm{Ma}$ off northwestern Greater India, well before and to the north of the Deccan traps. These authors show that such activity is compatible with the plume-head model. All published results (amount of composite section of lava pile, surface extent, histogram analysis with quality criteria) show that the bulk of Deccan trap volcanics erupted around K/T time in less than $1 \mathrm{Ma}, 50 \%$ at least of the volume being erupted within the 0.5-Ma-long reversed chron C29r, possibly in shorter but as yet unresolvable climactic episodes [30,32]. Widdowson [189] and Steve Self (pers. comm., 2002) point out the significance of an upward increasing number of intratrappean alteration levels (or 'red boles') that indicate a certain (unknown as yet) duration between flows, and the fact that there was a voluminous initial burst of volcanism followed by a decreasing trend, although an alternative explanation could be that the intensity of alteration was increasing upsection due to cumulatively increasing atmospheric $\mathrm{CO}_{2}$ concentration.

Scenarios of the climatic consequences of the Deccan traps have been sketched by many authors, starting with McLean's [111] $\mathrm{CO}_{2}$ crisis. This is reviewed by Wignall [190] and is not the focus of the present paper. The subsequent effects of short term cooling due to $\mathrm{H}_{2} \mathrm{SO}_{4}$ aerosols and longer term warming due to massive $\mathrm{CO}_{2}$ injection are still at the edge of paleoclimatic modeling capabilities (but see $[41,180]$ ). The major unknown is the duration of individual eruptions (e.g., [161]) and, just as important, the duration be- 
tween eruptions, i.e. the detailed shape of the forcing function. If eruptions are close in time, they may interact with varying phase between cooling and warming episodes, and can buildup faster than ocean equilibration times. Dessert et al. [41] propose a quantitative model of time evolution of surface temperature, ocean $\mathrm{pH}$ and $\mathrm{CO}_{2}$ atmospheric content: for instance, their model predicts that chemical erosion due to $\mathrm{HCO}_{3}{ }^{-}$ will lead to a global ${ }^{87} \mathrm{Sr} /{ }^{86} \mathrm{Sr}$ signal similar to the observed one, both in amplitude and shape, with both a transient and an irreversible part. This is a proxy that should be further studied at the times of other CFBs.

We should note at this point that there was a sealevel fall $100 \mathrm{kyr}$ before the Ir-defined K/T boundary. The low point occurred $10 \mathrm{kyr}$ before $\mathrm{K} / \mathrm{T}$ according to Hallam and Wignall [65], who attribute the subsequent rise and warming to Deccan eruptions and associated $\mathrm{CO}_{2}$ release. We will briefly return to the three time constants that are apparent in $\mathrm{K} / \mathrm{T}$ records (notably paleontological ones), i.e. long (10 Ma), shorter (1 Ma to $100 \mathrm{kyr}$ ) and very short (possibly instantaneous), in the discussion section.

\section{The Madagascar and Caribbean provinces}

The Caribbean-Columbian oceanic plateau is generally recognized as the tectonized remnant of a large eastern Pacific oceanic plateau (e.g., [94]). The deeper levels of the plateau have been exposed on its margins due to its mode of emplacement between the North and South American plates. The bulk of volcanism occurred between 91 and $88 \mathrm{Ma}$ in a number of short, discrete events [166]. The initial period lasted less than $2 \mathrm{Ma}$, but this cannot be constrained by magnetostratigraphy, because this was the time of the Cretaceous Long Normal Superchron. Ages are found to be synchronous over a large region, consistent with a flood basalt origin [166]. The volume of the plateau is thought to be of the order of $4 \mathrm{Mkm}^{3}$ and is dated at $89.5 \pm 0.3 \mathrm{Ma}$. It is linked by most authors to the birth of the Galapagos hot spot. A younger, widespread magmatic event occurred at about $70 \mathrm{Ma}$, but with much smaller volumes. It so happens that volumetrically smaller flood-like basalts are found in Madagascar at roughly the same age $\left({ }^{40} \mathrm{Ar} /{ }^{39} \mathrm{Ar}\right.$ ages $88.5 \pm 2.9,87.6 \pm 2.9 \mathrm{Ma}$ from [171]; see [190]). This is the time of only a modest extinction, but of one of the most widespread oceanic anoxic events (OAE) at the Cenomanian-Turonian boundary (93 Ma). There is also an extinction event at the end of the Turonian (89 Ma after [60]), hence a double event in the interval of 5 Ma. Kerr [93] has proposed a scenario for this event, in which volcanism-related $\mathrm{CO}_{2}$ leads to a runaway greenhouse climate and to global warming.

\section{The Kerguelen plateau}

The Kerguelen plateau in the southern Indian Ocean is the second largest oceanic plateau after the OntongJava plateau in the SW Pacific [25]. Its southern part, which is the largest, has recently been dated at 119$109 \mathrm{Ma}[26,44]$. Duncan [44] proposes that the entire plateau formed around $118 \mathrm{Ma}$, which is also the time of eruption of the Rajmahal traps in eastern India [92]. The Kerguelen plateau, Rajmahal traps, and Bunbury basalts in western Australia (erupted in two phases at 132 and $123 \mathrm{Ma}[55,56]$ ) were located close to each other at the time of eruption and roughly coeval with the breakup of eastern Gondwana. Ingle et al. [83] note that there are strong geochemical similarities within a first group, comprising a Bunbury group, a Rajmahal group, and one site in the south Kerguelen plateau, and also a second group, comprising another Bunbury group, another Rajmahal group, and a site to the northwest of the south Kerguelen plateau. Both groups could have originated from the Kerguelen plume, the first one being the only one to require input from depleted asthenospheric mantle. The first phase could correspond to a typical CFB, such as the ones in Greenland or Ethiopia, and the second phase to a burst prior to formation of oceanic crust as with the SDRS in the Brito-Arctic province or Afar stratoid series (see above). Ingle et al. [83] note that despite uncertainties on the time of rifting, geochemical and geophysical evidence requires the presence of a mechanism to isolate continental fragments during early breakup of eastern Gondwana and opening stages of the Indian Ocean. Though more data are required, we note that, in one interpretation, a joint $\mathrm{S}$. Kerguelen/Rajmahal/Bunbury CFB-like volcanic pulse may have occurred over a rather short interval of time near $118 \mathrm{Ma}$, i.e. the Late Barremian [44]. Alternately, this age is close to that of $117 \mathrm{Ma}$ assigned by Gradstein et al. [60] to the Early/Late Aptian boundary, a time 
of major biological crisis, far more significant than the end of the Barremian (Annie Arnaud-Vanneau, pers. comm., 2002). The Kerguelen plateau is unusual in several respects, notably because of a long magmatic history in which the plume 'tail' appears to have been more voluminous than the plume 'head'. Large volumes also erupted at $\sim 90 \mathrm{Ma}$, an age that coincides with the peaks of Caribbean and Madagascar volcanism. This may imply that the 90-Ma events were more widespread and could have had a larger environmental impact than generally suspected (Nick Arndt, pers. comm., 2002).

\section{The Ontong-Java plateau}

The Ontong-Java plateau in the southwestern Pacific is the largest of all oceanic plateaus, and is often considered to be the largest of all LIPs by an order of magnitude [25]. Its surface extent reaches $2 \mathrm{Mkm}^{2}$ and its mean crustal thickness is estimated at $36 \mathrm{~km}$, leading to a total volume of the order of $50 \mathrm{Mkm}^{3}$ [25], revised to $44.4 \mathrm{Mkm}^{3}$ by [48]. However, we have seen in the introduction that, for other flood basalts, neither underplated, lower-crust magmas, nor those injected within the crust are taken into account. Also, melt volume will be larger at the shallower depths of the suboceanic lithosphere. Finally, there is no mechanism to produce the major mechanical or chemical erosion that follows emplacement of subaerial continental traps [41]. That eruptions were submarine is documented by Saunders et al. [159]. If these are taken into account, the 'corrected' total volume of extruded, supracrustal Ontong-Java lavas may not exceed $6 \mathrm{Mkm}^{3}$. Mahoney et al. [113] argue that much of the plateau was emplaced over a rather brief time interval at $122 \mathrm{Ma}$, i.e. close to the end of the Barremian, at the time of a major anoxic event and also of global sea-level rise [175]. Neal et al. [127] recall that ages actually fall in two peaks, one at $\sim 122$ and one at $\sim 90$ Ma. Hallam and Wignall [66] propose that Early Cretaceous biota were largely immune to the effects of a major volcanic episode. Indeed, there is no mass extinction at that time, but the OAE argues for major environmental events. In qualitative models of the relationship between trap volcanism and environmental change (see [190] for a review), the main role is attributed to volcanic gases: $\mathrm{SO}_{2}\left(\mathrm{H}_{2} \mathrm{SO}_{4}\right)$ would even- tually lead to short-term cooling, whereas $\mathrm{CO}_{2}$ would lead to longer-term warming, with possible subsequent release of marine clathrates (methane hydrates) leading to a runaway greenhouse. But in the case of submarine volcanism, the enormous mass of ocean water is expected to act as a strong buffer, and $\mathrm{SO}_{2}$ is not expected to play a significant role (hence no mass extinction), whereas $\mathrm{CO}_{2}$ would still lead to water anoxia and a greenhouse period. In conclusion, there is a good case for a correlation between Ontong-Java volcanism and the end-Barremian OAE, and a mass extinction should not be expected because of suboceanic emplacement.

\section{The Paraná and Etendeka traps}

The Paraná traps in South America, together with their smaller severed counterpart at the Etendeka traps in Namibia and Angola, comprise a surface in excess of $1.5 \mathrm{Mkm}^{2}$ and an original volume in excess of $2.3 \mathrm{Mkm}^{3}$ [58]. Renne et al. [150] and Ernesto et al. [50] showed that most of the volcanism occurred at $\sim 133 \pm 1 \mathrm{Ma}$, based on ${ }^{40} \mathrm{Ar} /{ }^{39} \mathrm{Ar}$ plateau ages, and Renne et al. [150] further found that the total duration of trap volcanism could be constrained to $0.6 \pm 1 \mathrm{Ma}$. Based on data from cuttings retrieved from boreholes extending over a significant area of the traps, Stewart et al. [170] argued that volcanism extended from 138 to $128 \mathrm{Ma}$, spanning some $10 \mathrm{Ma}$. Even if uncertainties on ages derived from these particular samples (small cuttings from rocks having sojourned at rather warm temperatures with strong hydrothermal overprints) are discounted, it remains true, even for Stewart et al. [170], that the data histogram strongly peaks at $133 \mathrm{Ma}$, implying that a large fraction of trap volume was emplaced at that time. Also, since trap emplacement was followed by continental breakup and formation of the South Atlantic Ocean, a tail of younger volcanism is expected. Indeed, rift-related dikes are dated in coastal Brazil beginning around $128 \mathrm{Ma}$ [145]. The Etendeka traps are coeval with those of Paraná [152], including remnants as far north as Angola [117].

Taken at face value and using currently accepted numerical time scales, the age of the Paraná CFB corresponds to the end of the Valanginian. Although this is apparently often understated, the end of the 
Valanginian is a prominent extinction level. A major crisis for Bryozoan faunas and a cooling event have been noted by Walter [187] and Arnaud-Vanneau (pers. comm., 2002). This occurs near the base of the Trinodosum Zone (133-134 Ma if one follows the Gradstein et al. [60] time scale). A warming event follows at the end of the Callidiscus zone (133-132 Ma). On the other hand, the age of the Paraná CFB 'misses' the age of the Jurassic-Cretaceous boundary (not a prominent extinction either) by several Ma. Most current time scales give the $\mathrm{J} / \mathrm{K}$ boundary an age at $145 \mathrm{Ma}$, ranging between 149 and $139 \mathrm{Ma}$. Ogg and Lowrie [130] note that there is no internationally recognized standard for the $\mathrm{J} / \mathrm{K}$ boundary. Recently, Palfy et al. [134] compiled a revised Jurassic time scale. Based on the chronogram method, they proposed an age of 141.8/+2.5/-1.8 Ma. Deconinck et al. [40] determined low temperature $\mathrm{J} / \mathrm{K}$ boundary illites to be $122.3 \pm 2.3$ to $136.5 \pm 2.5 \mathrm{Ma}$ old, with the latter age being supposed close to $\mathrm{J} / \mathrm{K}$ age. Using the same material (and glauconites) Odin [129] proposes a $\mathrm{J} / \mathrm{K}$ age of $135 \pm 5 \mathrm{Ma}$, although the integrity of the $\mathrm{K}-\mathrm{Ar}$ system in these materials is open to question.

We note that the 40-km-diameter Morokweng crater in South Africa has been dated at 145 to $146 \mathrm{Ma}$ with a 1- to 2-Ma uncertainty (using Pb isotopes on zircons from the impact melt), and is considered by the authors as undistinguishable from the $\mathrm{J} / \mathrm{K}$ boundary [97].

We conclude that the Paraná-Etendeka province is the only major CFB that has not yet been conclusively shown to correlate with a clear, significant global paleoenvironmental event, even considering possible ambiguities in the definition and age of biostratigraphic boundaries in the Early Cretaceous. We suggest tentatively that several unique aspects of this CFB may explain its departure from the otherwise excellent correlation: (1) the relative paucity of primitive (asthenospheric) melts with high $\mathrm{S}$ and $\mathrm{CO}_{2}$ concentrations; (2) a substrate which was an extensive desert, lacking combustible biomass; (3) or maybe, as suggested by some (see above) to be the case for the E/O boundary, the $\mathrm{J} / \mathrm{K}$ boundary might be an artifact or a non-event [66], in any case not a major extinction level. But the traps could be coeval with younger than $\mathrm{J} / \mathrm{K}$ bioclimatic events at the end of the Valanginian.

\section{The Karoo and Farrar provinces}

The Karoo basalts in South Africa and Farrar volcanics extending for $4000 \mathrm{~km}$ throughout Antarctica are the remnants of a large CFB that erupted somewhat diachronously $[49,157]$ just prior to the breakup of Gondwana at $183 \pm 1 \mathrm{Ma}$ [46]. The total original volume of the $\mathrm{CFB}$, which extends over more than $6000 \mathrm{~km}$, was in excess of $2.5 \mathrm{Mkm}^{3}$. Using a revised time scale based on high precision $\mathrm{U}-\mathrm{Pb}$ ages, Palfy and Smith [135] suggested that the PliensbachianToarcian extinction lasted about $4 \mathrm{Ma}$ and peaked around $183 \mathrm{Ma}$. They argued in favor of simultaneity and causal connection between the flood basalts, an anoxic event, a rapid ${ }^{87} \mathrm{Sr} /{ }^{86} \mathrm{Sr}$ rise and biotic crises. Although the vast majority of Karoo basalts in South Africa, Lesotho and Namibia were extruded within $1 \mathrm{Ma}$ of $183 \mathrm{Ma}$ [46], Jones et al. [88] have recently found that igneous activity at the northwest extremity of the Province occurred at $\sim 180 \mathrm{Ma}$, in a short time span, but significantly younger than the main phase. These authors conclude that the duration of emplacement of the CFB was $~ 5$ Ma. However, this does not contradict the fact that the vast majority of the lava volume appears to have been extruded at $183 \mathrm{Ma}$ in about 1 Ma. Wignall [190] summarizes evidence for a link in time with the Late Pliensbachian-Early Toarcian extinction event, identified in NW European marine sections by Hallam [64] and then found in South America: this is a global event (and a second order yet significant extinction peak for Sepkoski [162]). This is biostratigraphically tied to the base of the Falciferum zone [135] (see also discussion by Wignall [190]). It is an anoxic event, and eruption of volcanic $\mathrm{CO}_{2}$ and ensuing global warming have been hypothesized as probable causes of the extinction [85]. Hesselbo et al. [72] identified a negative $\delta^{13} \mathrm{C}$ excursion, which, because of its amplitude and the low $\delta^{13} \mathrm{C}$ of volcanic $\mathrm{CO}_{2}$, they link with dissociation of $25 \%$ of the global gas hydrate reservoir subsequent to $\mathrm{CO}_{2}$-generated warming.

\section{The Central Atlantic Magmatic Province}

The Central Atlantic Magmatic Province (CAMP) is a relatively recent arrival in the series of large scale CFBs. Volcanic infilling of grabens on the East Coast of the US has been a topic of geological study for a 
long time, and the similarity between the age of the Palisades sills and that of the Triassic/Jurassic boundary was demonstrated by Dunning and Hodych [47]. Olsen et al. [131,132] emphasized the extent, age and short duration of these basalts (see also [110]). Using magnetostratigraphy and cyclostratigraphy, they were able to propose that the total duration of volcanism in the Newark and nearby basins did not exceed $580 \pm 100 \mathrm{ka}$. The onset of volcanism there appeared to be $30 \mathrm{~m}$ above the palynological $\mathrm{T} / \mathrm{J}$ boundary, corresponding to only a few tens of ka at most. Volcanism itself was dated at $201 \pm 1 \mathrm{Ma}$ [47,188], $199.5 \pm$ $2.0 \mathrm{Ma}\left({ }^{40} \mathrm{Ar} /{ }^{39} \mathrm{Ar}\right.$ on dykes [67]), and more recently 197-201 Ma [116,117]. These authors showed that the CAMP actually extended to West Africa, southwestern Europe and northeastern South America, originally covering up to $7 \mathrm{Mkm}^{2}$ (making it one of the widest in lateral extent) and exceeding $2 \mathrm{Mkm}^{3}$ in volume, all of which suggest a temporal link with the T/J boundary. Palfy et al. [135] dated a tuff layer in marine sediments encompassing the $\mathrm{T} / \mathrm{J}$ boundary; they obtained a U-Pb age on zircons of $199.6 \pm 0.3 \mathrm{Ma}$. Based on integration of ammonoid biostratigraphy and $\mathrm{U}-\mathrm{Pb}$ ages (leading to a $\mathrm{T} / \mathrm{J}$ age of $200 \pm 0.5 \mathrm{Ma}$ ), and on dating of T/J continental sections, Palfy et al. [135] suggested that the biotic crisis began on land a few $100 \mathrm{ka}$ before the marine extinction. Hesselbo et al. [73] have studied in detail both a T/J marine section from the UK and a terrestrial section from Greenland. These authors were able to identify a strong $\delta^{13} \mathrm{C}$ drop in both sections, synchronous with changes in flora and fauna in the two environments. Combined bio- and isotope stratigraphy make the correlation and evidence for synchroneity robust, and incidentally underline inadequacies in the use of traditional ammonite markers for the base of the Jurassic. Hesselbo et al. also show that the $\delta^{13} \mathrm{C}$ disturbance corresponds to a $\sim 600$-kalong climatic $\left(\mathrm{CO}_{2}\right)$ disturbance, which is the same order of magnitude as the duration of volcanism inferred by Olsen et al. [131], and is actually synchronous with the onset of CAMP eruptions, leading them to propose a causal link. The initial $\delta^{13} \mathrm{C}$ excursion is proposed as a suitable marker for the T/J boundary, and the minute timing differences emphasized by Olsen et al. [132] and Palfy et al. [135] remain to be evaluated on a global scale. Indeed, the fact that the first flows occur just slightly above the palynological $\mathrm{T} / \mathrm{J}$ boundary (continental palynological boundaries are not always very reliable) in the Newark basin are no proof that volcanism had not started earlier somewhere outside of the small graben within the huge CAMP.

Olsen et al. [133] very recently analyzed tetrapod footprints from North America, and found that theropod dinosaurs appeared less than $10 \mathrm{ka}$ after the T/J boundary. They also found (modest) iridium anomaly (140 ppt on average) and a fern spore spike, which they suggested were caused by a bolide impact. These authors concluded that an extrinsic environmental catastrophe occurred, which could have been an impact or a flood basalt. The evidence for impact is minimal and the time differences invoked are statistically insignificant at the scale of the whole CAMP, as stated above. Moreover, Olsen et al. mention that "the evolutionary hypothesis could be falsified by the discovery of large theropod bones". A large sauropod has been found in the Late Triassic of Thailand by Buffetaut et al. [17]. Therefore, the proposal of a $(10 \mathrm{ka})$ post $\mathrm{T} / \mathrm{J}$ impact is not supported, and the correlation of the entire $600 \mathrm{ka}$ period of intense bio-climatic disruption is much more reasonably attributed to CAMP volcanism and its environmental consequences.

\section{The Siberian traps}

The Siberian traps have now become among the better known of the huge flood basalt provinces. Although their central part now only covers some $0.4 \mathrm{Mkm}^{2}$, there is evidence that their extent was much greater. To the west, the traps have been found in drill holes and may extend below part of the large Kazakhstan Basin, which may correspond to an aborted attempt at rifting subsequent to trap eruption (e.g., [37]). A tectonized remnant of the traps is exposed in the Taymir region, to the north [63]. To the east and southeast, sills extend the total area of the province to at least $1.5 \mathrm{Mkm}^{2}$ [197]. Recently, Kravchinsky et al. [101] have shown that many of the kimberlite pipes lying east of the traps actually have the same paleomagnetic direction and age and correspond to early, highly explosive phases of the volcanism. Even more recently, Reichow et al. [147] have documented a subsurface extension of the traps nearly $1000 \mathrm{~km}$ west of the previously known limits of the province, in a drill core from the West Siberian basin. And Lyons et al. [108] show that magmatism of 
essentially the same age as the Siberian traps occurred as far south as central Kazakhstan. These suggest an area in excess of $4 \mathrm{Mkm}^{2}$ for the Siberian traps, and a volume in excess of $3 \mathrm{Mkm}^{3}$ and possibly significantly more $[37,148]$. In the central part, the traps are characterized by the occurrence of tuffs and numerous flows of the order of $10^{2}$ up to $10^{4} \mathrm{~km}^{3}$. The traps overlie Late Permian tuffs and have been dated by several authors in several locations. Renne and Basu [149] performed ${ }^{40} \mathrm{Ar} /{ }^{39} \mathrm{Ar}$ measurements on basalt flows extending over much of the main section of the traps and derived an age of $248.3 \pm$ $0.3 \mathrm{Ma}$ and a total duration of $0.9 \pm 0.8 \mathrm{Ma}$. This was later shifted (by recalibrating the Fish Canyon Tuff sanidine standard) to $250.0 \pm 1.6 \mathrm{Ma}$ [151]. Campbell et al. [21] dated zircons using $\mathrm{U}-\mathrm{Pb}$ via the SHRIMP ion microprobe to obtain $251.1 \pm 3.6 \mathrm{Ma}$. Kamo et al. [90] obtained a compatible U-Pb age of $251.2 \pm 0.3 \mathrm{Ma}$ on an intrusion in the lower part of the series. Magnetic stratigraphy [63,106] shows evidence for few reversals (only one is clear, with the possibility for other, shorter events which remain to be ascertained), consistent with a short total duration of volcanism. A compilation by Hofmann [76], paying particular attention to discrepancies between the ages of monitors used in several publications and producing some new ages, which considerably extend the surface of the sampling, confirms that the Siberian traps were extruded in probably less than $1 \mathrm{Ma}$ at about $250 \mathrm{Ma}$. Venkatesan et al. [184] confirmed a short duration of less than $1 \mathrm{Ma}$ from top to bottom of the pile, and their ages are consistent with the aforementioned ${ }^{40} \mathrm{Ar} /{ }^{39} \mathrm{Ar}$ results when normalized to the same standard.

The Permo-Triassic boundary has been dated thanks to the discovery of ash layers in the reference sections of Meishan and Shangsi in South China (minerals extracted from a bentonite), immediately below and above the paleontological boundary. The ash nearest the boundary (bed 25) at Meishan was dated at $251.2 \pm 3.4 \mathrm{Ma}$ by Claoué-Long et al. [24] (U-Pb on zircon), at $249.9 \pm 1.5 \mathrm{Ma}$ by Renne et al. [151] ( ${ }^{40} \mathrm{Ar} /{ }^{39} \mathrm{Ar}$ on sanidine), $251.4 \pm 0.3 \mathrm{Ma}$ by Bowring et al. [15] (U-Pb on zircon) and at $>253 \mathrm{Ma}$ by Mundil et al. [125,126] (U-Pb on zircon). Comparison of the ages from different radioisotopic systems is problematic, as previously discussed, underscoring the importance of the dating of both ash layer and trap samples with the same method, which allowed Renne et al. [153] to conclude that the difference between the two was $0.0 \pm 0.4 \mathrm{Ma}$, establishing within a few hundred thousand years the synchroneity of the climax of Siberian trap volcanism with the PT boundary (see also [190]). In any case, the bulk of available data show that most of Siberian trap volcanism did not span much more than $1 \mathrm{Ma}$. There was no documented subsequent successful rifting (apart from possible continental rifting in the Kazakhstan basin [37]) which may in part be responsible for the absence of an 'age tail', as found for instance in the Paraná. Basu et al. [12] determined an ${ }^{40} \mathrm{Ar} /{ }^{39} \mathrm{Ar}$ age of $253.0 \pm 2.6 \mathrm{Ma}$ in alkalic-ultramafic lavas infilling a pre-existing Late Permian graben in the Northeast; this might be an indication of a slightly older onset of volcanism, though we find little convincing evidence, for this (Wignall's figure 5 [190], comparing the timing of the various events, is misleading, because it ignores these uncertainties). The basal parts of the Siberian traps contain a high proportion of fragmental basaltic lavas. The source of these Siberian mafic tuffs is a matter of speculation (Nick Arndt, pers. comm., 2002). There may be a connection between them and the anhydriteand coal-rich sedimentary sequence that these magmas passed through on their way to the surface. The unique size and richness of the Noril'sk-Talknakh ore deposits may be due to this interaction. The major impact that the Siberian traps have had on the environment could be linked with the explosive eruption of $\mathrm{S}$ - and $\mathrm{CO}_{2}$-rich basalts [21]. The kimberlite pipes to the east and the swath of silicic volcanic centers to the south (e.g., [108]) attest to the importance of this form of volcanism, with significant implications for transporting volcanic gases high into the upper atmosphere and ensuring subsequent global distribution.

Extinction patterns at the P/T boundary and extinction mechanisms have been reviewed by Wignall [190]. There now appears to be no doubt that the Siberian trap eruptions played a central role in what seems to be the largest Phanerozoic extinction event. Holser and Magaritz [80] had clearly emphasized the importance of events occurring in the $15 \mathrm{Ma}$ period from the Late Permian to the Early Triassic, though until recently the absence of geochronological data has hindered quantitative understanding of the time scales of these events. They noted dramatic shifts in marine isotopic compositions of $\mathrm{C}, \mathrm{S}$ and $\mathrm{Sr}$. Several shortterm excursions of $\delta^{13} \mathrm{C}$, with a final drop at the $\mathrm{P} / \mathrm{T}$ 
boundary, a sharp rise of ${ }^{87} \mathrm{Sr} /{ }^{86} \mathrm{Sr}$ after the boundary (because of increased continental weathering and acid rain; see the analysis by Dessert et al. [41] for the $\mathrm{K} / \mathrm{T}$ boundary and Deccan traps summarized above), and most notably the waning of Late Paleozoic glaciations and rapid rise of sea level underlined the major climatic disturbances near the P/T boundary and their correlation with a major biotic event. It is now known that the time scale of these events is relatively compressed (i.e., of the order of $1 \mathrm{Ma}$ between the regression and the P/T boundary [154]) but not instantaneous. The role of explosive volcanism that initially induces cooling was emphasized by Campbell et al. [21] (see also [100]). A major subsequent phase of global warming is then observed, and volcanic $\mathrm{CO}_{2}$ injection has been proposed as a driving mechanism [27, $41,115]$. This would also be responsible for a 'superanoxic' event in the marine realm [190]. The dramatic $\delta^{13} \mathrm{C}$ anomaly is now attributed to catastrophic release of highly volatile methane hydrates (chlathrates) buried at shallow depths [42], leading to a runaway greenhouse. This event is in turn assumed to have been triggered by the massive release of volcanic $\mathrm{CO}_{2}$. To be complete, we should mention the finding by Smith and Ward [168] of an 'event bed' in continental sections of the P/T boundary in South Africa, where mass extinction of terrestrial fauna and flora seems to have occurred in less than $50 \mathrm{ka}$, which the authors correlate with a catastrophic event. A pattern of gradual disappearance of fossils below the boundary is interpreted to be an artifact due to the Signor-Lipps effect [165]. However, the short time estimate of Smith and Ward [168] is based on a sedimentological indicator, namely estimates of flood plain accretion rates whose calibration is questionable, and there is as yet no available geochronologic control. Evidence for a bolide impact at P/T time has proven irreproducible $[52,84]$ and contentious [98].

\section{The Emeishan traps}

Another, less advertised yet prominent flood basalt province of Late Permian age occurs in southwestern China. The Emeishan basalts outcrop over an area in excess of half a million square kilometers (e.g., $[195,196])$. They have been considered as being a true flood basalt province linked to a starting plume by
Chung et al. [23]. Since their formation, the Emeishan traps have been severely broken up, deformed and eroded. Extrusion of Indochina to the southeast by more than $500 \mathrm{~km}$, shear along the Ailao Shan-Red River fault zone and thrusting of Tibet along the Long Men Shan has resulted in major tectonic disruption of the former province, part of which can be traced far to the south, having been displaced by the Red River fault zone. Based on these, on the findings of the basalts in petroleum drill cores in the Sichuan basin and on observation of feeder dykes in the Yuanmou-Xichang region, Zhou et al. [196] estimate that the traps initially covered an area in excess of 2 , and possibly as much as $5 \mathrm{Mkm}^{2}$. Their thickness ranges from a few hundred meters up to $5 \mathrm{~km}$, often in the $1-2-\mathrm{km}$ range. The original volume therefore must have been in excess of $1 \mathrm{Mkm}^{3}$.

The Emeishan basalts overlie the Early Permian Maokou Formation, and are overlain by the Late Permian Xuanwei and Wujiaping formations. The Wujiaping sedimentary sequence is of Wuchiapingian or Dzhulfian age [193]. The Dzhulfian immediately follows the Midian (and Wuchiapingian follows the Maokou); they are assumed to be lateral equivalents of the Guadalupian. Therefore, stratigraphic data suggest that the Emeishan traps were near the end of the Guadalupian, i.e. about 258 Ma old (see also [23,86]).

The Emeishan traps are interesting in that they illustrate in a way the applicability and 'predictive' power of the hypothesis that most major traps are linked to a major bioclimatic event (ocean anoxic event or mass extinction; e.g. $[31,37,189]$ ). Based on detailed analysis of the ratio of rates of extinction vs rates of origination, Stanley and Yang [169] discovered that the end of the Permian was actually marked not by one prolonged, but rather by two distinct and rather short extinction events. The one that preceded the terminal P/T boundary extinction occurred at the end of the Guadalupian, and some 5 to $8 \mathrm{Ma}$ (depending on geological time scales, which in 1994 were considerably less accurate than implied by these numbers) before the Permo-Triassic boundary proper. Holser and Magaritz [80] had already pointed out that two sharp minima of sea level occurred at these two times. Wignall [190] notes that the earlier minimum was a major regional regression, and corresponded to an alltime low point of sea level in the Phanerozoic. Hallam and Wignall [66] and Courtillot et al. [37] in- 
dependently proposed that the Emeishan traps were erupted at the end of the Guadalupian, causing the earlier phase of mass extinction, cooling and growth of continental ice, resulting sea-level drop and possibly rifting along the margins of the early Tethys. Based on magnetostratigraphic analysis (a single chron was found), Huang et al. [82] and Huang and Opdyke [81] have proposed that the overall duration of the event was short, as found in most other CFBs, probably less than $1 \mathrm{Ma}$.

Two recent studies have attempted to determine the absolute age of the Emeishan basalts. Zhou et al. [196] analyzed zircons from the Xinjie sill, which intrudes the traps and is interpreted as part of the feeder system of the main phase of eruption. They obtained a ${ }^{206} \mathrm{~Pb} /{ }^{238} \mathrm{U}$ SHRIMP age of $259 \pm 3 \mathrm{Ma}$, consistent with an end-Guadalupian extinction. On the other hand, Lo et al. [107] used ${ }^{40} \mathrm{Ar} /{ }^{39} \mathrm{Ar}$ and inferred a main stage of flood magmatism at $\sim 251-253 \mathrm{Ma}$, and subordinate activity at $\sim 255 \mathrm{Ma}$. According to this interpretation, the main phase is somewhat older than the generally accepted ${ }^{40} \mathrm{Ar} /{ }^{39} \mathrm{Ar}$ age of the P-T boundary and Siberian traps, yet younger than both the Guadalupian-Tatarian boundary and the age from Zhou et al. [196]. This is not consistent with a number of stratigraphic constraints, particularly the observation that the Emeishan Traps are unequivocally older than the end of the Wuchiapingian stage (see above), which has been dated recently at $255 \mathrm{Ma}$ by ${ }^{40} \mathrm{Ar} /{ }^{39} \mathrm{Ar}$ [195] and $260 \mathrm{Ma}$ by U/Pb [125,126]. It should be noted that the standard (LP-6) used as a neutron fluence monitor by Lo et al. [107] is known to be heterogeneous [11] and the basis for normalization to other standards may be compromised. We conclude that, although a correlation between the Emeishan Traps and the terminal Guadalupian extinction appears likely, inconsistencies in the dating must be resolved. Wignall [190] points out that the much smaller Panjal volcanics in northwestern India $\left(12000 \mathrm{~km}^{2}\right.$, maximum thickness of $2.5 \mathrm{~km}$ ) have essentially the same stratigraphic age.

\section{The 'Viluy' traps}

In his review, Wignall [190] notes the lack of pre-Permian LIPs, with no example found from the 240 Ma span from the Cambrian to the Middle Per- mian. Although Wignall also notes the absence of major rifting episodes during this interval, the large mass extinction at the Frasnian-Fammenian boundary (360 Ma) begs for a causative source. The crisis is marked by extinction of diverse marine groups, anoxia and rapid sea-level fluctuations. Minor, yet interesting volcanism is noted by several authors to have happened at about this time. Recent work [192] reveals basement uplift, magmatism and rifting in the Kola, Vyatka and Pripyat-Dniepr-Donets provinces, spanning almost $2000 \mathrm{~km}$ on the East European platform. Drilling and seismic data from the Pripyat-DnieprDonets rift system demonstrate rifting and intense volcanic activity in the Late Devonian. Two distinct sequences are recognized, respectively at the end of the Frasnian (364 Ma) and Famennian (354 Ma), when two major extinction events occurred (perhaps a double event as in the case of the end-Guadalupian and end-Permian extinctions?). Magmas with kimberlitic affinity are associated with the early stages. The period of most intense volcanism apparently coincides with a maximum of extension, and also with peak uplift on rift flanks. Dolerite dykes are widespread, whereas tholeiitic basaltic lavas occur only as erosional remnants of what Wilson et al. [192] assume to have been a much more extensive volcanic province. Lithospheric stretching factors appear too small for melting to have been driven by extension alone: volatiles in the lower lithosphere and asthenosphere, or an anomalously hot mantle due to a plume are invoked by the authors. This is supported by $\mathrm{Sr}-\mathrm{Nd}$ isotopic characteristics and large depths of origin (over $200 \mathrm{~km}$ ) for at least some of the magmas. Therefore, volcanics in the PripyatDnieper-Donets rift system have the appropriate age $[141,191]$, but they are apparently volumetrically minor $\left(<10000 \mathrm{~km}^{3}\right)$.

Racki and House [142] review details of the transition, and note that "it is an inescapable conclusion (...) that all recently refined data support a long continued, multicausal interpretation of the F/F extinctions and an Earth-bound crisis rather than a worldwide cosmic cataclysm". They emphasize the need for better radiometric dating of the contemporary volcanic activity, and of the age of the F/F boundary itself.

Kravchinsky et al. [101] studied basaltic sills and dykes, and kimberlite pipes from the eastern part of the Siberian platform. These are spread out over a few hundred kilometers in the Mir, Aikhal and Olenyek 
regions and in the Viluy and Markha basins, and Aikhal region. The sites can be divided in groups that yield distinct paleomagnetic poles. One group is consistent with the Siberian traps pole; the associated kimberlite pipes are evidence for an early violent phase of volcanism. The other group averages at a distinct position and corresponds to a separate family of kimberlite pipes.

Radioisotopic data for the kimberlites and biostratigraphic age estimates have been summarized in Brakhfogel [16], Krivonos [102], and Griffin et al. [61]. There are significant differences between the age estimates of different pipes obtained by different methods. Griffin et al. [61] emphasized this problem for different kimberlite fields, especially for the $\mathrm{K}-\mathrm{Ar}$ method, and in several cases in contradiction with reliable geological dating, which suggests excess of argon. Presently, the age interval cannot be constrained to better than 377-350 Ma [101], which contains the age of the Frasnian-Fammenian extinction. It is therefore hard to escape the hypothesis that these kimberlite pipes could be all that remains of a major CFB that caused the extinction. Coeval volcanism occurs in the Donets and in the Kola Peninsula; hence, the original surface extent might have been similar to that of the CAMP. Samples have recently been obtained from the pipes and are being independently dated at the OrsayIPGP and Berkeley facilities. Regarding the F/F extinctions, Uysal et al. [182] provided K-Ar data for clays from the Woodleigh impact structure in western Australia, which were interpreted to date the impact at ca $360 \mathrm{Ma}$. We refer to the problems with this interpretation that were raised by Renne et al. [155], and reiterate that an impact origin for this event is not supported by the available data.

\section{Pre-Devonian traps}

Although a trap that could be linked with the previous (first) largest Phanerozoic mass extinction at the Ordovician-Silurian boundary remains to be found, some mention can be made of pre-Devonian traps. The $~ 723$-Ma Natkusiak flood basalts on Victoria Island are located at a Neoproterozoic triple junction between Laurentia and Siberia [136]. It was noted [37] that this was close to the onset of silica biomineralization and to some major early phases of bi- ological radiation of eukaryotic organisms. Very recently, Goddéris et al. [59] have built on the mechanism of Dessert et al. [41] to propose that the $\sim 700$ Ma Snowball Earth event was triggered by massive flood basalt volcanism, as Rodinia was rifted to produce the proto-Pacific ocean. Other examples [3] include the $\sim 800-\mathrm{Ma}$ 'Antrim' basalts of western and central Australia, the $\sim 1.1-\mathrm{Ga}$ Keewanawan basalts, the $\sim 1.2-\mathrm{Ga}$ Coppermine River basalts, the $\sim 1.8-\mathrm{Ga}$ Eskimo basalts in the Belcher Islands and the oldest well-preserved suite of continental flood basalts at $\sim 2.7 \mathrm{Ga}$ (the Fortescue and Ventersdopr basalts [4]). A recent SHRIMP age of $513 \pm 12$ Ma has been determined by Hanley and Wingate [69] for an EarlyCambrian dolerite dyke corresponding to an intrusive phase of the Antrim Plateau volcanics. This is Australia's largest Phanerozoic flood basalt province, with an unknown original surface that must have been well in excess of $300000 \mathrm{~km}^{2}$. This is very close to the major Archeocyatid extinction and Trilobite turnover that marks the Early-Middle Cambrian boundary (Joe Kirschvink, pers. comm., 2002). If petrological and geochemical arguments are accepted, most basalts and komatiites of Archean and Early-Proterozoic greenstone belts were once parts of oceanic plateaus: Arndt et al. [4] describe a long history of plume-related magmatism in western Australia, in which 3.2- and 3.5-Ga ultramafic and mafic volcanics apparently also formed as parts of oceanic plateaus such as Ontong Java. Ernst and Buchan [51] have reviewed a database of possible LIPs extending back to $3.8 \mathrm{Ga}$, and have recognized as many as 31 well-established events related to an arriving mantle plume head, and six clusters of synchronous plumes (lumping the Deccan and Greenland traps, the Ontong-Java young phase with Madagascar and Caribbean, the Ontong-Java older phase and Manihiki plateaus, the Parana and Etendeka, the Karoo and Ferrar, and finally the Mackenzie dyke swarm and Central Scandinavian dolerite complex at $1270 \mathrm{Ma}$ ). From this, they infer maximum size and time distribution in time and space of plumes, in particular an average rate of about one plume per $20 \mathrm{Ma}$ [51].

\section{Discussion and conclusion}

Continental flood basalts, and the corresponding submarine oceanic plateaus, are quite impressive and 
unique geological features. Their rarity is remarkable, and a rather complete catalogue (of the order of a dozen) is becoming available for the last 300 or even $400 \mathrm{Ma}$ (Table 1). Of course, a number of LIPs could have escaped detection, because they were subducted, accreted as allochtonous terranes, destroyed in collision zones, or buried by sediments (unlikely). Contrary to a number of other geodynamic phenomena, CFB volumes do not follow a scaling law: there are not far more smaller than larger events. On the contrary, CFBs (together with OPs, i.e. all LIPs) form a quasi unimodal distribution (Table 1): in terms of probable original volumes (e.g., [41]), the Ethiopian traps were in excess of $1 \mathrm{Mkm}^{3}$, the NATVP, Deccan, Paraná, CAMP, Karoo and Emeishan in excess of $2 \mathrm{Mkm}^{3}$, the Siberian traps in excess of $3 \mathrm{Mkm}^{3}$, and the Caribbean and Ontong Java in excess of $4 \mathrm{Mkm}^{3}$. Only the Columbia River, and possibly Panjal were an order of magnitude smaller. There are not, as might have been expected, a much larger number of Columbia-size traps than Deccan-size traps. This might be due to the fact that the (plume) process that leads to a CFB must have a minimum size in order to erupt through the lithosphere, and a maximum one linked to the maximum available energy. That a small plume such as the one that produced the Columbia FB could erupt through the lithosphere may be due to the fact that the region had been undergoing significant extension and thinning prior to eruption.

LIPs have been tentatively associated in one way or another (through time correlation) with events originating from the core (such as major changes in reversal frequency and long superchrons, e.g., [33]), through the mantle [123], to the lithosphere with continental breakup (e.g., [37,74]) and all the way to the biosphere with the proposed link with mass extinction and ocean anoxia events (e.g., [31, $32,143,174,189])$. These suggestions all rely on the accuracy of dating of the CFBs. We have shown in this review that, despite insufficient numbers of data and remaining uncertainties in available data (differences between laboratories, techniques, rocks measured, standards, alteration...), most if not all LIPs seem to share a common time pattern (a testable hypothesis), in which volcanism may span some $10 \mathrm{Ma}$, but where the bulk of the lava (say more than $80 \%$ in volume) is emitted in a duration of the order of or shorter than 1 million years. This in itself is an important geodynamical observation. If there were about 15 such events in the last $300 \mathrm{Ma}$ of Earth history, we may say that the Earth was in a period of peak CFB volcanism five per cent of the time, assuming 1 Ma duration. Associated mean fluxes were from 1 to $5 \mathrm{~km}^{3}$ per year, and could have peaked at much higher values if the larger volume and shorter time estimates apply, and if the actual time distribution (bunching) of individual flows was non uniform, as is likely (see for instance the red bole distribution in the Deccan, or the accurate dates on silicic phases of volcanism in the Ethiopian traps). These rates can be compared to the annual production of oceanic crust, of the order of 20-25 km³/yr (e.g., [160]), or the annual flux from present day hot spots (i.e. plume tails, see [156]), of the order of $0.5 \mathrm{~km}^{3} \mathrm{yr}^{-1}$ (e.g., [167]). They are clearly of major potential geodynamic significance. On the other hand, there is no indication of significant trends in (extrusive) crustal production rates, contrary to what is found by other authors (e.g., Fig. 5a in [48]). These 'trends' were largely biased by the heterogeneous estimate of the volume of the Ontong-Java plateau (see above).

Now, the present state of absolute dating of traps is also interesting. The correlation first proposed by Rampino and Stothers [143] and Courtillot [31] has steadily improved, with smaller uncertainties and more successful correlations (Fig. 1). The most recent of the largest mass extinctions (following Sepkoski [162]; modified following Stanley and Young [169]) correspond to a well dated trap: Deccan for the end-Cretaceous, CAMP for the end-Triassic, Siberian traps for the end-Permian and Emeishan traps for the end-Guadalupian. The next older one, the 'Viluy' traps may have been found and are currently being dated. Of all main Paleozoic mass extinctions, only the Ordovician one would remain to be found. Most other CFBs and other LIPs are now associated with either a second-order mass extinction, or a major bioclimatic event, or an ocean-anoxia event. Two apparent exceptions are the Ethiopian traps (which do not correspond to the Eocene-Oligocene boundary, yet this is a secondary bio-event and major bio-climatic disruptions may be coeval with the traps at the time of the Oi2 event), and the Paraná-Etendeka traps (which do not correlate with the Jurassic-Cretaceous boundary, which is not a major extinction level, but may correlate with the end-Valanginian biotic crisis). 


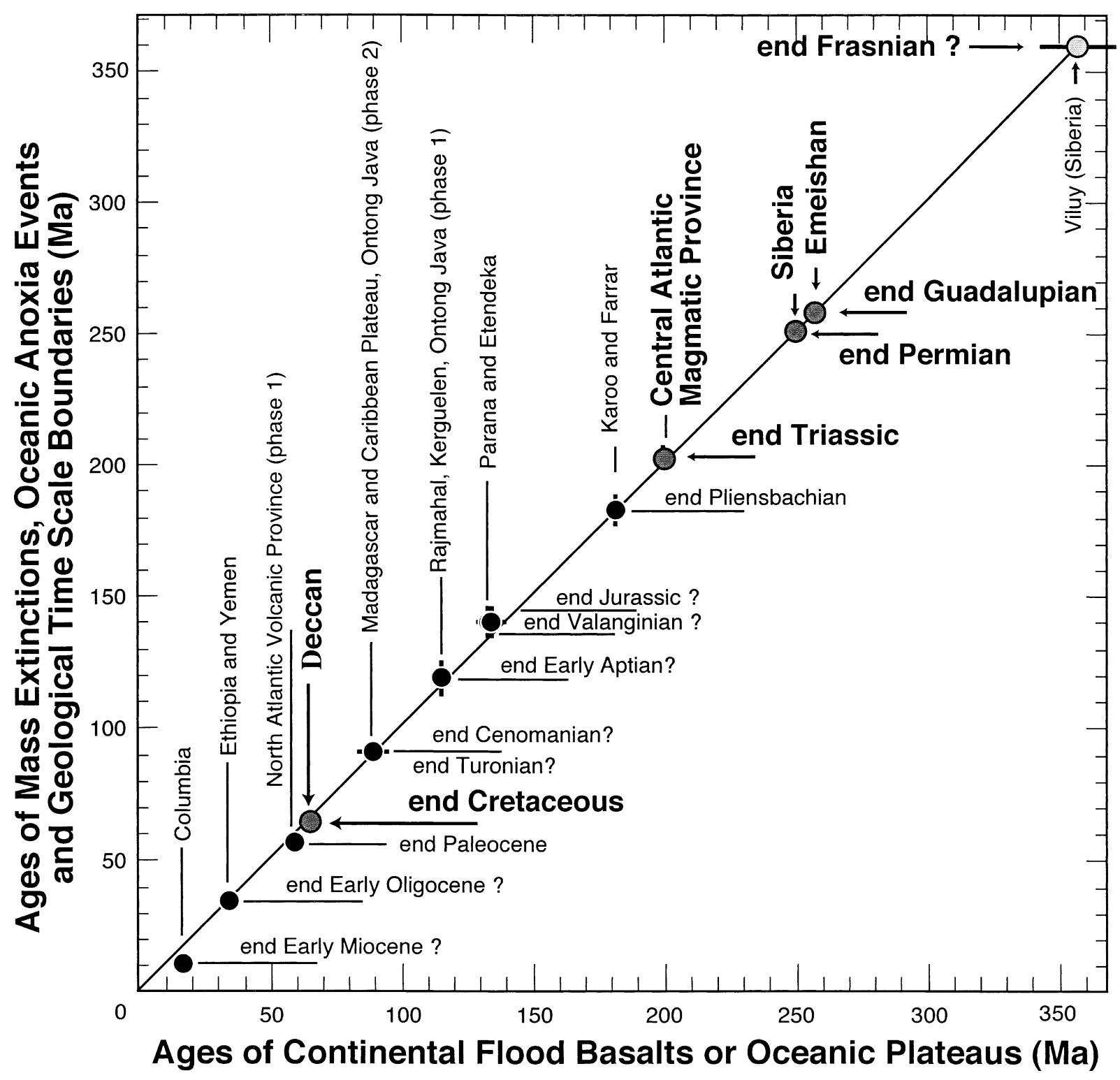

Fig. 1. Correlation between the ages of LIPs (CFBs and OPs) on one hand, and those of mass extinctions and oceanic anoxia events on the other hand (all in Ma). This figure is updated from [31] and some later versions; see also [143] for what may be the first such plot. Values are from Table 1 and are discussed in the text. Uncertainties are visible only when they are larger than the diameters of the dots corresponding to individual events. The four largest recent mass extinctions and corresponding traps are in dark grey, the previous one in light grey is being radiometrically dated.

Fig. 1. Corrélation entre les âges des grandes provinces magmatiques (LIP) et ceux des extinctions en masse et des événements anoxiques océaniques (tous en Ma). Cette figure complète et met à jour celle de la référence [31] et de versions ultérieures ; voir aussi [143] pour ce qui est sans doute la première version de ce type de figure. Les valeurs viennent du Tableau 1 et sont discutées dans le texte. Les barres d'incertitude ne sont visibles que quand elles sont supérieures au diamètre des points correspondant à chaque événement. Les quatre plus grandes extinctions récentes et les trapps correspondants sont en gris foncé, le précédent en gris clair étant en cours de datation radiométrique. 
One might ask whether any CFB activity could be related to the Cambrian explosion. We have seen that the Antrim CFB has an age compatible with the biotic crisis at the end of the Early Cambrian. At the time of the explosion, the background rate of speciation was approximately 20 times larger than the average rate for the entire Mesozoic and over a dozen oscillations in inorganic $\delta^{13} \mathrm{C}$, lasting less than $1 \mathrm{Ma}$ each, correlate to biological evolutionary events (Kirschvink and Raub, this issue). Although individual events may bear some relation with features of individual $\mathrm{CFBs}$, this unique succession of many events in a short time may make a CFB connection unlikely. In this issue, Kirschvink and Raub propose a scenario involving a 'methane fuse' to explain the Cambrian explosion, the carbon cycles, and related episodes of true polar wander.

One should of course at this point emphasize that the Chicxulub impact is thought by many authors to be the single cause of the end-Cretaceous extinction: these authors had naturally expected that other impacts would mark other extinctions. However, as noted by Alvarez [2], the Chicxulub impact remains the only one with a clear time correspondence to a mass extinction, despite two decades of hard work to find others. And there are a number of reasonably large and welldated craters that correspond to no extinction or other geologically recorded bio-event. A recent paper by Jones et al. [89] proposes a model of impact-induced decompression melting as a possible mechanism for CFB generation. Based on hydrodynamic modeling, the authors propose instantaneous melting followed by long-lived mantle upwelling, and suggest that the endPermian Siberian traps should be reconsidered as the result of a major impact. The mechanism may well be possible (analyzing it would be beyond the scope of this paper, and of our abilities), but it is easy to show that when the idea is applied to actual data, it is untenable for Earth LIPs. The paper unfortunately fails to quote a wealth of field, geochronologic, paleomagnetic and other published evidence on (i) the duration of LIP volcanism, (ii) the detailed dating of the Siberian traps and Meishan sections, (iii) the fact that the K/T Ir level is within the reversed chron 29R in the Deccan, hundreds of thousands of years after the onset of volcanism, (iv) the fact that field evidence for an impact at $\mathrm{P} / \mathrm{T}$ time has been at best equivocal, attempts to replicate the results being unsuccessful... The dis- cussion and conclusion of Jones et al. [89] are largely unsubstantiated, as can readily be seen from the data and observations recalled in the present review.

Climatic scenarios have been constructed to account for changes in the ocean and atmosphere imparted by a major impact (e.g., $[137,138,178]$ ) and a flood basalt or oceanic plateau event (see [41,59], or Fig. 6 in [190]). Pope [139] has actually shown that the original $\mathrm{K} / \mathrm{T}$ impact extinction scenario, formulated in terms of the shutdown of photosynthesis by submicron size dust, was not valid. Although much work remains to be done, it appears that both types of phenomena can lead to disruption of the climate and biosphere on a global scale, via $\mathrm{SO}_{2}$ and $\mathrm{CO}_{2}$ emission, succeeding episodes of cooling and warming, acid rain, etc.

Our main point is that all major extinctions in the last $300 \mathrm{Ma}$ have an associated trap, but only one has an impact. Few major flood basalts have no associated bio- or climatic disruption, whereas many impacts have no such associated sequence. We grant that the Chicxulub impact is the largest known on Earth, yet it might (given uncertainties) be the only such event in the whole Phanerozoic, i.e. a once per billion year event, rather than a once per $100 \mathrm{Ma}$ event, as generally assumed - estimates of terrestrial meteoritic infall being extremely poorly calibrated. Also, we should point out that there is good evidence that a flood basalt alone can produce a mass extinction, whereas the only clear evidence for impact is at a time when a flood basalt event was already underway. Indeed, discovery of the Iridium anomaly in sediments in the Kutch region of the Deccan $[14,38]$ shows that volcanism had been going on for a (few) hundred thousand years before the bolide hit. It can therefore be proposed that the impact immediately led to extinctions of large numbers of already stressed species, explaining at the same time why other large impacts have no associated extinction, and why the Chicxulub effect did have such large, quasi instantaneous effects. Therefore, the 'impact' and 'volcanic' hypotheses for mass extinctions should not be opposed. That the K/T impact did occur seems clear, as does the fact that the Deccan erupted around $\mathrm{K} / \mathrm{T}$ time. But our analysis leads us to propose the hypothesis that LIP volcanism was the main agent of mass extinction in the Phanerozoic, whereas impacts were likely the prominent agent of change in the first billion years of Earth history. Should the above analysis be vindicated by further (much needed) work, 
it appears that ages of LIPs could be used as tie points and references for many key boundaries of the geological time scale at least at the $1 \mathrm{Ma}$ absolute age uncertainty level. In that sense, much more joint geochronological (coupled with magnetostratigraphic, biostratigraphic and geochemical) work by several laboratories (cross-checking their instruments and standards) appears to be well worth the effort.

Altogether, three different time scales of extinction have been documented: the ultra-short one linked to impact (one example), the geologically catastrophic but slower one, of the order of $10^{5}$ to $10^{6}$ years, linked to the peak emission of a flood basalt province (some fifteen examples), and a slower geological one of the order of $10^{7}$ years, corresponding to regressiontransgression events. Some ten examples, often at the same general time as CFBs, are discussed in detail by Hallam and Wignall [65]. The end-Cretaceous extinction is associated with a major regression. Severe regression is also found at the end-Guadalupian and end-Triassic events. But the Frasnian-Famennian is a time of sea-level highstand, and the end-Permian extinction is argued by Hallam and Wignall [65] to have been a time of major transgression. These authors conclude that rapid high-amplitude regressivetransgressive couplets are frequently observed at times of mass extinctions. LIPs and regression or transgression events can be causally related through Earth convective processes of different speed and efficiency. Long-term regression and transgression are related to changes in mid-ocean ridge volumes through changes in global plate velocities. They reflect changes in the intensity of 'normal' mantle convection, but may also be related to the impingement of superplumes at the base of the lithosphere (e.g., [65]). Short-term LIPs are related to plumes, i.e. instabilities which provide another, sometimes more efficient, mode of evacuation of excess heat from the Earth's (deep) mantle (see, e.g., $[20,62])$. In a recent review of details in the pattern of extinctions at the Cretaceous-Tertiary boundary in the marine realm, Keller [91] argues that the boundary kill-effect was largely restricted to tropical and subtropical populations that had already been severely reduced and actually accounted for less than $10 \%$ of the total foraminiferal population. The paleontological record therefore seems to support both long-term (climate, sea level) and short-term (impact, volcanism) time scales in the mass extinction pattern [91]. The oc- currence of impact and CFB at the K/T can only be a coincidence, and, as suggested above, the K/T impact effects may have been vastly amplified by prestressing due to the Deccan CFB and might not have been so noticeable otherwise.

In a bold paper, Morgan et al. [124] believe that geologic evidence for four coincidences between impact signals and flood basalts imply causal links (we believe only one such coincidence is well established). Morgan et al. propose a model in which conditions associated with cratonic flood basalts may trigger both a geologic 'impact signal' and a mass extinction. The link is a huge explosive carbon-rich gas release event triggered by plume incubation. These authors argue that explosive deep lithospheric blasts can create shock waves, cavitation and mass-jet formation, and transport a large mass of shocked crust into superstratospheric trajectories. However novel and interesting, this suggestion needs be invoked only when 'impact signals' are observed, and we believe that such is the case only at the K/T boundary. Still, it is the first time an internal dynamic process is suggested that could produce shocked minerals, the best evidence for meteorite impact so far.

Finally, we note that details of the specific paleoenvironmental effects - the killing mechanisms - of CFB/LIP emplacement remain fuzzy because the atmospheric loading history of volcanogenic volatiles during these events is not known with sufficient resolution. It is therefore desirable, and should become a future research priority, to develop dating methods capable of resolving time within a sequence of flood basalt eruptions. Particularly promising are dating methods based on accumulation of cosmogenic nuclides, which could potentially measure the amount of time a given flow top is exposed before becoming shielded from cosmic radiation by the subsequent flow. Also, it remains a significant challenge to petrologists to quantify the amounts of various volatile species actually delivered by LIP's to the atmosphere. It is gratifying that this fundamental outstanding problem seems to be receiving some attention lately, and we look forward with optimism that improved estimates will be forthcoming.

\section{Acknowledgements}

Much of this paper was prepared while V.C. enjoyed a Moore Fellowship for which he is particu- 
larly grateful to Caltech, and to its Division of Planetary and Geological Sciences and to its Chairman Ed Stolper. We thank Louis de Bonis for pointing out the paper by Buffetaut et al. [17]. We thank Stuart Gilder and Xavier Quidelleur for careful reading and comments, Annie Arnaud-Vanneau for suggestions, and Nick Arndt and Mike Coffin for extensive comments and suggestions. IPGP Contribution NS 1853.

\section{References}

[1] C.J. Allègre, J.L. Birck, F. Capmas, V. Courtillot, Age of the Deccan traps using Re-187-Os-187 systematics, Earth Planet. Sci. Lett. 170 (1999) 197-204.

[2] W. Alvarez, Compiling the evidence for impact at seven mass extinctions, abstract in Impacts and the origin, evolution, and extinction of life, Rubey colloquium, UCLA, 3-7, 2002.

[3] N.T. Arndt, F. Albarède, E.G. Nisbet, Mafic and ultramafic magmatism, in: M.J. de Wit, L.D. Ashwal (Eds.), Greenstone Belts, Oxford Science Publications, Oxford, 1997, pp. 233254.

[4] N.T. Arndt, G. Bruzak, T. Reischmann, The oldest continental and oceanic plateaus - Geochemistry of Basalts and Komatiites of the Pilbara Craton, Australia, in: K.L. Buchan, R.E. Ernst (Eds.), Mantle plumes: their identification through time, Boulder, CO, Geol. Soc. Am. Spec. Pap. 352 (2001) 359-389.

[5] M.P. Aubry, C.C. Swisher, D.V. Kent, W.A. Bergren, Paleogene time scale miscalibration: evidence from the dating of the North Atlantic igneous province. Comment, Geology (submitted).

[6] D. Ayalew, P. Barbey, B. Marty, L. Reisberg, G. Yirgu, R. Pik, Source, genesis, and timing of giant ignimbrite deposits associated with Ethiopian continental flood basalts, Geochim. Cosmochim. Acta 66 (2002) 1429-1448.

[7] S. Bajpai, Fossil records in the rich Deccan intertrappean beds, Anjar: data and inferences, Deccan trap basalts and the K/T boundary, Phys. Res. Lab., Ahmedabad, India, 1999, Abstracts, pp. 1-2.

[8] S. Bajpai, G.V. Prasad, Cretaceous age for Ir-rich Deccan intertrappean deposits: paleontological evidence from Anjar, western India, J. Geol. Soc. Lond. 157 (2000) 257-260.

[9] J.L. Baker, M.M. Snee, A brief Oligocene period of flood volcanism in Yemen: implications for the duration and rate of continental flood volcanism at the Afro-Arabian triple junction, Earth Planet. Sci. Lett. 138 (1996) 39-55.

[10] A.K. Baksi, E. Farrar, Ar-40/Ar-39 dating of the Siberian traps, USSR - Evaluation of the ages of the 2 major extinction events relative to episodes of flood-basalt volcanism in the USSR and the Deccan traps, India, Geology 19 (1991) 461464.

[11] A.K. Baksi, D.A. Archibald, E. Farrar, Intercalibration of ${ }^{40} \mathrm{Ar} /{ }^{39} \mathrm{Ar}$ dating standards, Chem. Geol. 129 (1996) 307324.
[12] A.R. Basu, R.J. Poreda, P.R. Renne, F. Teichmann, Y.R. Vasiliev, N.V. Sobolev, B.D. Turrin, High He3 plume origin and temporal-spatial evolution of the Siberian flood basalts, Science 269 (1995) 822-825.

[13] F. Begemann, K.R. Ludwig, G.W. Lugmair, K. Min, L.E. Nyquist, P.J. Patchett, P.R. Renne, C.-Y. Shih, I.M. Villa, R.J. Walker, Call for an improved set of decay constants for geochronological use, Geochim. Cosmochim. Acta 65 (2001) 111-121.

[14] N. Bhandari, P.N. Shukla, Z.G. Ghevariya, S. Sundaram, Impact did not trigger Deccan volcanism: evidence from Anjar K/T boundary intertrappean sediments, Geophys. Res. Lett. 22 (1995) 433-436.

[15] S.A. Bowring, D.H. Erwin, Y. Jin, M.W. Martin, K. Davidek, $\mathrm{W}$. Wang, U/Pb zircon geochronology and tempo of the endPermian mass extinction, Science 280 (1998) 1039-1045.

[16] F.F. Brakhfogel, Geological aspects of kimberlite magmatism in the northeastern Siberian Platform, Publishing of the Yakutian Institute of Geology, Russian Academy of Sciences, Yakutsk, 1984, 463 p. (in Russian).

[17] E. Buffetaut, et al., The first giant dinosaurs: a large sauropod from the Late Triassic of Thailand, C. R. Palevol 1 (2002) 103-109.

[18] K. Caldeira, M.R. Rampino, Carbon-dioxide emissions from Deccan volcanism and a K/T-boundary greenhouse effect, Geophys. Res. Lett. 17 (1990) 1299-1302.

[19] V.E. Camp, M.E. Ross, Mapping the Steens-Columbia River basalt connection: implications for the extent, volume, and magma supply rate of CFB volcanism, Geol. Soc. Am. Abstr. with Programs 32 (7) (2000) A159.

[20] I.H. Campbell, R.W. Griffiths, Implications of mantle plume structure for the evolution of flood basalts, Earth Planet. Sci. Lett. 99 (1990) 79-93.

[21] I.H. Campbell, G.K. Czamanske, V.A. Fedorenko, R.I. Hill, V. Stepanov, Synchronism of the Siberian traps and the Permian-Triassic boundary, Science 258 (1992) 1760-1763.

[22] L.M. Chambers, M.S. Pringle, Age and duration of activity at the Isle of Mull Tertiary igneous centre, Scotland, and confirmation of the existence of subchrons during Anomaly 26r, Earth Planet. Sci. Lett. 193 (3-4) (2001) 333-345.

[23] S.L. Chung, B.M. Jahn, G. Wu, C.H. Lo, B. Cong, The Emeishan flood basalt in SW China: a mantle plume initiation model and its connection with continental breakup and mass extinction at the Permian-Triassic boundary, in: M.F.J. Flower, S.L. Chung, C.H. Lo, T.Y. Lee (Eds.), Mantle Dynamics and Plate Interactions in East Asia, AGU Geodynamics Series 27 (1998) 47-58.

[24] J.C. Claoué-Long, Z. Zhang, G. Ma, S. Du, The age of Permian-Triassic boundary, Earth Planet. Sci. Lett. 105 (1991) 182-190.

[25] M.F. Coffin, O. Eldholm, Large igneous provinces - Crustal structure, dimensions, and external consequences, Rev. Geophys. 32 (1994) 1-36.

[26] M.L. Coffin, M.S. Pringle, R.A. Duncan, T.P. Gladczenko, M. Storey, Kerguelen hot spot magma output since $130 \mathrm{Ma}$, J. Petrol. 43 (2002) 1121-1139. 
[27] P.J. Conaghan, S.E. Shaw, J.J. Veevers, Sedimentary evidence of the Permian/Triassic global crisis induced by the Siberian hotyspot, Can. Soc. Pet. Geol. Mem. 17 (1994) 785-795.

[28] E. Coulié, Chronologie ${ }^{40} \mathrm{Ar} /{ }^{39} \mathrm{Ar}$ et $\mathrm{K} / \mathrm{Ar}$ de la déchirure continentale en Afar depuis $30 \mathrm{Ma}, \mathrm{PhD}$ thesis, University Paris-Sud, France, 2001, 331 p.

[29] E. Coulié, X. Quidelleur, P.-Y. Gillot, V. Courtillot, J.-C. Lefèvre, S. Chiesa, Comparative K-Ar and Ar/Ar dating of Ethiopian and Yemenite Oligocene volcanism: implications for timing and duration of the Ethiopian traps, Earth Planet. Sci. Lett. 206 (2003) 477-492.

[30] V. Courtillot, A volcanic eruption?, Sci. Am. 263 (1990) 8592.

[31] V. Courtillot, Mass extinctions in the last 300 million years: One impact and seven flood basalts?, Isr. J. Earth Sci. 43 (1994) 255-266.

[32] V. Courtillot, Evolutionary Catastrophes: The Science of Mass Extinction, Cambridge University Press, Cambridge, 1999, $171 \mathrm{p}$.

[33] V. Courtillot, J. Besse, Magnetic field reversals, polar wander, and core-mantle coupling, Science 237 (1987) 1140-1147.

[34] V. Courtillot, J. Besse, D. Vandamme, J.-J. Jaeger, R. Montigny, Deccan trap volcanism as a cause of biologic extinctions at the Cretaceous-Tertiary boundary?, C. R. Acad. Sci. Paris, Ser. II 303 (1986) 863-868.

[35] V. Courtillot, J. Besse, D. Vandamme, R. Montigny, J.-J. Jaeger, H. Cappetta, Deccan flood basalts at the Cretaceous/Tertiary boundary?, Earth Planet. Sci. Lett. 80 (1986) 361-374.

[36] V. Courtillot, G. Féraud, H. Maluski, D. Vandamme, M.G. Moreau, J. Besse, The Deccan flood basalts and the Cretaceous-Tertiary boundary, Nature 333 (1988) 843-845.

[37] V. Courtillot, C. Jaupart, I. Manighetti, P. Tapponnier, J. Besse, On causal links between flood basalts and continental breakup, Earth Planet. Sci. Lett. 166 (1999) 177-195.

[38] V. Courtillot, Y. Gallet, R. Rocchia, G. Féraud, E. Robin, C. Hofmann, N. Bhandari, Z.G. Ghevariya, Cosmic markers, ${ }^{40} \mathrm{Ar} /{ }^{39} \mathrm{Ar}$ dating and paleomagnetism of the KT sections in the Anjar area of the Deccan large igneous province, Earth Planet. Sci. Lett. 182 (2000) 137-156.

[39] V. Courtillot, A. Davaille, J. Stock, J. Besse, Three distinct types of hot spots in the Earth's mantle, Earth Planet. Sci. Lett. 205 (2003) 295-308.

[40] J.-F. Deconinck, P.-Y. Gillot, M. Steinberg, A. Strasser, Syndepositional, low temperature illite formation at the JurassicCretaceous boundary (Purbeckian) in the Jura Mountains (Switzerland and France); K/Ar and $\delta^{18} \mathrm{O}$ evidence, Bull. Soc. géol. France 172 (2001) 343-348.

[41] C. Dessert, B. Dupré, L.M. François, J. Schott, J. Gaillardet, G. Chakrapani, S. Bajpai, Erosion of Deccan traps determined by river geochemistry: impact on the global climate and the ${ }^{87} \mathrm{Sr} /{ }^{86} \mathrm{Sr}$ ratio of seawater, Earth Planet. Sci. Lett. 188 (2001) 459-474.

[42] G.R. Dickens, C.K. Paull, P. Wallace, Direct measurement of in-situ methane quantities in a large gas-hydrate reservoir, Nature 385 (1997) 426-428.
[43] A.P. Dickin, The North Atlantic tertiary province, in: J.D. MacDougall (Ed.), Flood Basalts, Kluwer Academic Publishers, Hingham, MA, 1988, pp. 111-149.

[44] R.A. Duncan, A timeframe for construction of the Kerguelen Plateau and Broken Ridge, J. Petrol. (in press).

[45] R.A. Duncan, D.G. Pyle, Rapid eruption of the Deccan flood basalts at the Cretaceous/Tertiary boundary, Nature 333 (1988) 841-843.

[46] R.A. Duncan, P.R. Hooper, J. Rehacek, J.S. Marsh, A.R. Duncan, The timing and duration of the Karoo igneous event, southern Gondwana, J. Geophys. Res. 102 (1997) 1812718138.

[47] G.R. Dunning, J.P. Hodych, U/Pb zircon and baddeleytic ages for the Palisades and Gettysburg sills of the northeastern United States: implications for the age of the Jurassic/Triassic boundary, Geology 18 (1990) 795-798.

[48] O. Eldholm, M.F. Coffin, Large Igneous Provinces and Plate Tectonics, in: The History and Dynamics of Global Plate Motions, in: Geophys. Monogr., Vol. 121, 2000, pp. 309-326.

[49] J. Encarnacion, T.H. Fleming, D.H. Elliot, H.V. Eales, Synchronous emplacement of Ferrar and Karoo dolerites and the early breakup of Gondwana, Geology 24 (1996) 535-538.

[50] M. Ernesto, M.I.B. Raposo, L.S. Marques, P.R. Renne, L.A. Diogo, A. de Min, Paleomagnetism, geochemistry and ${ }^{40} \mathrm{Ar} /{ }^{39} \mathrm{Ar}$ dating of the north-eastern Paraná Magmatic Province: tectonic implications, J. Geodyn. 28 (1999) 321340.

[51] R.E. Ernst, K.L. Buchan, Maximum size and distribution in time and space of mantle plumes: evidence from large igneous provinces, J. Geodyn. 34 (2002) 309-342.

[52] K.A. Farley, S. Mukhopadyay, An extraterrestrial impact at the Permian-Triassic boundary?, Science 293 (2002) 2343a (technical comments, www.sciencemag.org).

[53] G. Féraud, V. Courtillot, Did Deccan volcanism pre-date the Cretaceous-Tertiary transition - Comment, Earth Planet. Sci. Lett. 122 (1994) 259-262.

[54] F. Fluteau, G. Ramstein, J. Besse, Simulating the evolution of the African and Indian monsoons during the past 30 Ma using atmospheric general circulation model, J. Geophys. Res. 104 (1999) 11995-12018.

[55] F.A. Frey, N.J. McNaughton, D.R. Nelson, J.R. de Laeter, R.A. Duncan, Petrogenesis of the Bunbury basalt, western Australia: interaction between the Kerguelen plume and Gondwana lithosphere?, Earth Planet. Sci. Lett. 144 (1996) 163-183.

[56] F.A. Frey, et al., Origin and evolution of a submarine large igneous province: the Kerguelen Plateau and Broken Ridge, southern Indian ocean, Earth Planet. Sci. Lett. 176 (2000) 73 89.

[57] L. Geoffroy, J.-P. Callot, S. Scaillet, A. Skuce, J.-P. Gélard, M. Ravilly, J. Angelier, B. Bonin, C. Cayet, K. Perrot, C. Lepvrier, Southeast Baffin volcanic margin and the North American-Greenland plate separation, Tectonics 20 (2001) 566-584.

[58] T.P. Gladczenko, K. Hinz, O. Eldholm, H. Meyer, S. Neben, J. Skojseid, South Atlantic volcanic margins, J. Geol. Soc. Lond. 154 (1997) 465-470. 
[59] Y. Goddéris, Y. Donnadieu, A. Nédélec, B. Dupré, C. Dessert, A. Grard, G. Ramstein, L.M. François, The Sturtian 'snowball' glaciation: fire and ice, Earth Planet. Sci. Lett. (submitted).

[60] F.M. Gradstein, F.P. Agterberg, J.G. Ogg, J. Hardenbol, P. van Veen, J. Thierry, Z. Huang, A Mesozoic time scale, J. Geophys. Res. 99 (1994) 24051-24074.

[61] W.L. Griffin, C.G. Ryan, F.V. Kaminsky, S.Y. O’Reilly, L.M. Natapov, T.T. Win, P.D. Kinny, I.P. Ilupin, The Siberian lithosphere traverse: mantle terranes and the assembly of the Siberian Craton, Tectonophysics 310 (1999) 1-35.

[62] R.W. Griffiths, I.H. Campbell, Interaction of mantle plume heads with the Earth's surface and onset of small-scale convection, J. Geophys. Res. 96 (1991) 18295-18310.

[63] E. Gurevitch, M. Westphal, J. Daragan-Suchov, H. Feinberg, J.-P. Pozzi, A.N. Khramov, Paleomagnetism and magnetostratigraphy of the traps from western Taymir (northern Siberia) and the Permo-Triassic crisis, Earth Planet. Sci. Lett. 136 (1995) 461-473.

[64] A. Hallam, Cyclothems, transgressions and faunal change in the Lias of North West Europe, Trans. Edinburgh Geol. Soc. 18 (1961) 132-174.

[65] A. Hallam, Mass Extinctions and their Aftermath, Oxford University Press, Oxford, UK, 1997, 320 p.

[66] A. Hallam, P.B. Wignall, Mass extinctions and sea-level changes, Earth Sci. Rev. 48 (1999) 217-250.

[67] W.E. Hames, P.R. Renne, C.R. Ruppel, New evidence for geologically-instantaneous emplacement of Earliest Jurassic Central Atlantic magmatic province basalts on the North American margin, Geology 28 (2000) 859-862.

[68] M.A. Hamilton, D.G. Pearson, R.N. Thompson, S.P. Kelley, C.H. Emeleus, Rapid eruption of Skye lavas inferred from precise $\mathrm{U}-\mathrm{Pb}$ and $\mathrm{Ar}-\mathrm{Ar}$ dating of the Rum and Cuillin plutonic complexes, Nature 394 (6690) (1998) 260-263.

[69] L. Hanley, M. Wingate, SHRIMP zircon age for an Early Cambrian dolerite dyke: an intrusive phase of the Antrim Plateau Volcanics of northern Australia, Austr. J. Earth Sci. 47 (6) (2000) 1029-1040.

[70] H.J. Hansen, D.M. Mohabey, P. Toft, No K/T boundary at Anjar, Gujarat, India: evidence from magnetic susceptibility and carbon isotopes, Proc. Indian Acad. Sci., Earth Planet. Sci. 110 (2001) 133-142.

[71] B.U. Haq, J. Hardenbol, P.R. Vail, Chronology of fluctuating sea levels since the Triassic, Science 235 (1987) 1156-1166.

[72] S.P. Hesselbo, D.R. Gröcke, H.C. Jenkyns, C.J. Bjerrum, P. Farrimond, H.S. Morgans Bell, O.R. Green, Massive dissociation of gas hydrate during a Jurassic oceanic anoxic event, Nature 406 (2000) 392-416.

[73] S.P. Hesselbo, S.A. Robinson, F. Surlyk, S. Piasecki, Terrestrial and marine extinction at the Triassic-Jurassic boundary synchronized with major carbon-cycle perturbation: a link to initiation of massive volcanism?, Geology 30 (2002) 251254.

[74] R.I. Hill, Starting plumes and continental breakup, Earth Planet. Sci. Lett. 104 (1991) 398-416.

[75] K. Hinz, A hypothesis on terrestrial catastrophes wedges of very thick oceanward dipping layers beneath passive margins, Geol. Jahrb. 22 (1981) 5-28.
[76] C. Hofmann, Datation ${ }^{40} \mathrm{Ar} /{ }^{39} \mathrm{Ar}$ et paléomagnétisme des traps d'Éthiopie, du Deccan et de Sibérie, Thesis, University Paris-7-IPGP, Paris, France, 1997, 200 p.

[77] C. Hofmann, V. Courtillot, G. Féraud, P. Rochette, G. Yirgu, E. Ketefo, R. Pik, Timing of the Ethiopian flood basalt event and implications for plume birth and global change, Nature 389 (1997) 838-841.

[78] C. Hofmann, G. Féraud, V. Courtillot, Ar-40/Ar-39 dating of mineral separates and whole rocks from the Western Ghats lava pile: further constraints on duration and age of the Deccan Traps, Earth Planet. Sci. Lett. 180 (2000) 13-27.

[79] W.S. Holbrook, H.C. Larsen, J. Korenaga, T. Dahl-Jensen, J.D. Reid, P.R. Kelemen, J.R. Hopper, G.M. Kent, D. Lizzaralde, S. Bernstein, R.S. Detrick, Mantle thermal structure and active upwelling during continental breakup in the North Atlantic, Earth Planet. Sci. Lett. 190 (2001) 251-266.

[80] W.T. Holser, M. Magaritz, Events near the Permian-Triassic boundary, Mod. Geol. 11 (1987) 155-180.

[81] K. Huang, N.D. Opdyke, Magnetostratigraphic investigations of an Emeishan basalts section in western Guizhou Province, southwest China, Abstract, Fall Meeting, American Geophysical Union, Transactions AGU 77 (1996) F171.

[82] K. Huang, N.D. Opdyke, X. Peng, J. Li, Paleomagnetic results from the Upper Permian of the eastern Qiangtang terrane of Tibet and their tectonic implications, Earth Planet. Sci. Lett. 111 (1992) 1-10.

[83] S. Ingle, D. Weis, J.S. Scoates, F.A. Frey, Relationship between the early Kerguelen plume and continental flood basalts pf the paleo-Eastern Gondwanan margins, Earth Planet. Sci. Lett. 197 (2002) 35-50.

[84] Y. Isozaki, An extraterrestrial impact at the Permian-Triassic boundary?, Science 293 (2002) 2343a (technical comments, www.sciencemag.org).

[85] H.C. Jenkyns, Mesozoic anoxic events and palaeoclimate, Zentralbl. Geol. Palaeontol. 1 (1999) 943-949.

[86] Y. Jin, J. Shang, The Permian of China and its interregional correlation, in: H. Yin, J.M. Dickins, G.R. Shi, J. Tong (Eds.), Permian-Triassic evolution of Tethys and western circumPacific, in: Developments in Paleontology and Stratigraphy, Vol. 18, Elsevier, Amsterdam, 2000, pp. 71-98.

[87] D.W. Jolley, B. Clarke, S. Kelley, Paleogene timescale miscalibration: evidence from the dating of the North Atlantic igneous province, Geology 30 (2002) 7-10.

[88] D.L. Jones, R.A. Duncan, J.C. Briden, D.E. Randall, C. McNiocaill, Age of the Batoka basalts, northern Zimbabwe, and the duration of the Karoo Large Igneous province magmatism, Geochem. Geophys. Geosyst. 2 (2001), Pap. No. 2000GC000110.

[89] A.P. Jones, G.D. Price, N.J. Price, P.S. DeCarli, R.A. Clegg, Impact-induced melting and the development of large igneous provinces, Earth Planet. Sci. Lett. 202 (2002) 541-561.

[90] S.L. Kamo, G.K. Czamanske, T.E. Krogh, A minimum $\mathrm{U}-\mathrm{Pb}$ age for Siberian flood basalt volcanism, Geochim. Cosmochim. Acta 60 (1996) 3505-3511.

[91] G. Keller, The end-Cretaceous mass extinction in the marine realm: year 2000 assessment, Planet. Space Sci. 49 (2001) $817-830$. 
[92] R.W. Kent, M.S. Pringle, R.D. Müller, A.D. Saunders, N.C. Ghose, ${ }^{40} \mathrm{Ar} /{ }^{39} \mathrm{Ar}$ geochronology of the Rajmahal basalts, India, and their relationship to the Kerguelen Plateau, J. Petrol. (in press).

[93] A.C. Kerr, Oceanic plateau formation: a cause of mass extinction and black shale deposition around the CenomanianTuronian boundary, J. Geol. Soc. Lond. 155 (1998) 619-626.

[94] A. Kerr, J. Tarney, G. Marriner, A. Nivia, A. Saunders, The Caribbean-Colombian Cretaceous Igneous Province: the internal anatomy of an oceanic plateau, in: J.J. Mahoney, M.F. Coffin (Eds.), Large Igneous Provinces: Continental, Oceanic and Planetary Flood Volcanism, American Geophysical Union, Washington, 1997, pp. 123-144.

[95] B. Kieffer, N. Arndt, H. Lapierre, F. Bastien, A. Pécher, F. Keller, C. Meugniot, G. Yirgu, D. Ayalew, D. Bosch, D. Weis, D.A. Jerram, The transition from plateau to shield volcanism in Ethiopia: a petrological and geochemical study, J. Petrol. (submitted).

[96] K.B. Knight, P.R. Renne, A. Halkett, N. White, ${ }^{40} \mathrm{Ar} /{ }^{39} \mathrm{Ar}$ dating of the Rajahmundry Traps, eastern India, and their relationship to the Deccan Traps, Earth Planet. Sci. Lett. (in press).

[97] C. Koeberl, R.A. Armstrong, W.U. Reimold, Morokweng, South Africa: a large impact structure of Jurassic-Cretaceous boundary age, Geology 25 (1997) 731-734.

[98] C. Koeberl, L. Gilmour, W.U. Reimold, P. Claeys, B. Ivanov, End-Permian catastrophe by bolide impact: Evidence of a gigantic release of sulfur from the mantle: comment, Geology 30 (2002) 855-856.

[99] M.A. Kominz, S.F. Pekar, Oligocene eustacy from twodimensional sequence startigraphic backstripping, Geol. Soc. Am. Bull. 113 (2002).

[100] H.W. Kozur, Some aspects of the Permian-Triassic boundary (PTB) and of the possible causes for the biotic crisis around this boundary, Palaeogeogr. Palaeoclimatol. Palaeoecol. 143 (1998) 227-272.

[101] V.A. Kravchinsky, K.M. Konstantinov, V. Courtillot, J.I. Savrasov, J.-P. Valet, S. Chernyi, S. Mishenin, B. Parasotka, Paleomagnetism of East Siberian traps and kimberlites: two new poles and paleogeographic reconstructions at about 360 and 250 Ma, Geophys. J. Int. 148 (2002) 1-33.

[102] V.F. Krivonos, Relative and absolute age of kimberlites, Otechestvennaya Geologiya 1 (1997) 41-51 (in Russian).

[103] R.A. Lange, Constraints on the preeruptive volatile concentrations in the Columbia River flood basalts, Geology 30 (2002) 179-182.

[104] H.C. Larsen, A.D. Saunders, Tectonism and volcanism at the southeast Greenland rifted margin: a record of plume impact and later continental rupture, in: A.D. Saunders, H.C. Larsen, S.W. Wise Jr. (Eds.), Proc. ODP, Sci. Results, College Station, TX, Ocean Drilling Program 152 (1998) 503-533.

[105] S.W. Leavitt, Annual volcanic carbon dioxide emission: an estimate from eruption chronologies, Environ. Geol. 4 (1982) 15-21.

[106] E.N. Lind, S.V. Kropotov, G.K. Czamanske, S.C. Grommé, V.A. Fedorenko, Paleomagnetism of the Siberian flood basalts of the Noril'sk area: a constraint on eruption duration, Int. Geol. Rev. 36 (1994) 1139-1150.
[107] C.H. Lo, S.L. Chung, T.Y. Lee, G. Wu, Age of the Emeishan flood magmatism and relations to Permian-Triassic boundary events, Earth Planet. Sci. Lett. 198 (2002) 449-458.

[108] J.O. Lyons, R.S. Coe, X. Zhao, P.R. Renne, A.Y. Kazansky, A.E. Izokh, L.V. Kungurtsev, D.V. Mitrokhin, Paleomagnetism of the Early Triassic Semitau Igneous Series E. Kazakhstan, J. Geophys. Res. 107 (2002), 10.1029/2001JB000521.

[109] G.R. McGhee, The 'multiple impact hypothesis' for mass extinction: a comparison of the Late Devonian and the Late Eocene, Palaeogeogr. Palaeoclimatol. Palaeoecol. 176 (2001) 47-58.

[110] J.G. McHone, Broad-terrane Jurassic flood basalts across northwestern North America, Geology 24 (1996) 319-322.

[111] D.M. McLean, Mantle degassing unification of the TransK-T geobiological record, Evol. Biol. 19 (1985) 287-313.

[112] J.J. Mahoney, M.F. Coffin, Large igneous provinces: continental, oceanic, and planetary flood volcanism, Geophys. Monogr. 100 (1997) 1-438.

[113] J.J. Mahoney, M. Storey, R.A. Duncan, K.J. Spencer, M. Pringle, Geochemistry and geochronology of Leg130 basement lavas: nature and origin of the Ontong-Java Plateau, in: W.H. Berger (Ed.), Proc. Ocean Drilling Prog. 130 (1993) 3-22.

[114] J.J. Mahoney, R.A. Duncan, W. Khan, E. Gnos, G.R. McCormick, Cretaceous volcanic rocks of the South Tethyan suture zone, Pakistan: implications for the Réunion hot spot and Deccan traps, Earth Planet. Sci. Lett. 203 (2002) 295-310.

[115] E.E. Martin, J.J. Macdougall, $\mathrm{Sr}$ and $\mathrm{Nd}$ isotopes at the Permian/Triassic boundary: a record of climate change, Chem. Geol. 125 (1995) 73-100.

[116] A. Marzoli, P.R. Renne, E.M. Piccirillo, M. Ernesto, G. Bellieni, A. De Min, Extensive 200 million year old continental flood basalts of the central Atlantic magmatic province, Science 284 (1999) 616-618

[117] A. Marzoli, L. Melluso, V. Morra, P.R. Renne, I. Sgrosso, M. D’Antonio, L. Duarte, E.A.A. Morais, E.A.A. Morais, G. Ricci, Geochronology and petrology of cretaceous basaltic magmatism in the Kwanza Basin (western Angola), and relationships with the Paraná-Etendeka flood basalt province, J. Geodyn. 28 (1999) 341-356.

[118] M.A. Menzies, J. Baker, D. Bosence, C. Dart, I. Davison, A. Hurford, M. Al'Kadasi, K. McClay, G. Nichols, A. Al Subbary, A. Yelland, The timing of magmatism, uplift and crustal extension: preliminary observations from Yemen, in: B.C. Storey, T. Alabaster, R.J. Pankhurst (Eds.), Magmatism and the Causes of Continental Breakup, Geol. Soc. Spec. Publ. 68 (1992) 293-304.

[119] K.G. Miller, J.D. Wright, R.G. Fairbanks, Unlocking the ice-house: Oligocene-Miocene oxygen isotopes, eustacy and margin erosion, J. Geophys. Res. 96 (1991) 6829-6848.

[120] K. Min, R. Mundil, P.R. Renne, K.R. Ludwig, A test for systematic errors in ${ }^{40} \mathrm{Ar} /{ }^{39} \mathrm{Ar}$ geochronology through comparison with $\mathrm{U}-\mathrm{Pb}$ analysis of a 1.1-Ga rhyolite, Geochim. Cosmochim. Acta 64 (1) (2000) 73-98.

[121] P. Mohr, B. Zanettin, The Ethiopian flood basalt province, in: J.D. MacDougall (Ed.), Continental Flood Basalts, Kluwer, Dordrecht, The Netherlands, 1998, pp. 63-110. 
[122] A. Montanari, A. Deino, R. Coccio, V.E. Langenheim, R. Capo, S. Monechi, Geochronolgy, Sr isotope analysis, magnetostratigraphy, and plankton stratigraphy across the Oligocene-Miocene boundary in the Contessa section (Gubbio, Italy), Newslett. Stratigr. 23 (1991) 151-180.

[123] W.J. Morgan, Hot spot tracks and the opening of the Atlantic and Indian oceans, in: C. Emiliani (Ed.), The Sea, Vol. 7, Wiley Interscience, New York, 1981, pp. 443-487.

[124] J.P. Morgan, T.J. Reston, C.R. Ranero, Mass extinctions, continental flood basalts, and 'impact signals': are mantle plume-induced 'Verneshots' the causal link?, Earth Planet. Sci. Lett. (submitted).

[125] R. Mundil, I. Metcalfe, K.R. Ludwig, P.R. Renne, F. Oberli, R.S. Nicoll, Timing of the Permian-Triassic biotic crisis: implications for new zircon $\mathrm{U} / \mathrm{Pb}$ age data (and their limitations), Earth Planet. Sci. Lett. 187 (2001) 133-147.

[126] R. Mundil, K. Ludwig, P.R. Renne, I. Metcalf, Constraints on the timing of the Permian-Triassic biotic crisis: new U/Pb zircon ages, EOS Trans. Am. Geophys. Un. 82 (2001) 1384.

[127] C.R. Neal, J.J. Mahoney, L.W. Kroenke, R.A. Duncan, M.G. Petterson, The Ontong-Java Plateau, in: J.J. Mahoney, M.F. Coffin (Eds.), Large igneous provinces: continental, oceanic and planetary flood volcanism, Am. Geophys. Union, Washington, DC, 1997, pp. 183-216.

[128] R.D. Norris, U. Rohl, Carbon cycling and chronology of climate warming during the Paleocene-Eocene transition, Nature 401 (1999) 775-778.

[129] G.S. Odin, Geological time scale, C. R. Acad. Sci. Paris, Ser. II 318 (1994) 59-71.

[130] J.G. Ogg, W. Lowrie, Magnetostratigraphy of the Jurassic/Cretaceous boundary, Geology 14 (1986) 547-550.

[131] P.E. Olsen, R.W. Schlische, M.S. Fedosh, 580-Kyr duration of the Early Jurassic flood basalt event in eastern North America estimated using Milankovitch cyclostratigraphy, in: M. Morales (Ed.), The Continental Jurassic Museum of Northern Arizona Bull. 60 (1996) 11-22.

[132] P.E. Olsen, D.V. Kent, S.J. Fowell, Causal association of the Triassic-Jurassic mass extinction and Pangean flood basalt a matter of timing, 1997 Am. Geophys. Union Fall Meeting, Abstract volume, EOS Transactions AGU 78 (1997) F721 (abstract).

[133] P.E. Olsen, D.V. Kent, H.D. Sues, C. Koeberl, H. Huber, A. Montanari, E.C. Rainforth, S.J. Fowell, M.J. Szajna, B.W. Hartline, Ascent of dinosaurs linked to an iridium anomaly at the Triassic-Jurassic boundary, Science 296 (2002) 1305-1307.

[134] J. Palfy, P.L. Smith, Synchrony between Early Jurassic extinction, oceanic anoxic event, and the Karoo-Ferrar flood basalt volcanism, Geology 28 (2000) 747-750.

[135] J. Palfy, P.L. Smith, J.K. Mortensen, A U-Pb and ${ }^{40} \mathrm{Ar} /{ }^{39} \mathrm{Ar}$ time scale for the Jurassic, Can. J. Earth Sci. 37 (2000) 923944.

[136] S.M. Pelechaty, Stratigraphic evidence for the SiberiaLaurentia connection and Early Cambrian rifting: reply, Geology 25 (1997) 571-572.

[137] E. Pierazzo, Climatic effects produced by stratospheric loading of S-bearing gases released in the Chicxulub impact event, abstract in Impacts and the origin, evolution, and extinction of life, Rubey colloquium, UCLA, 2002, pp. 45-46.

[138] E. Pierazzo, D.A. Kring, H.J. Melosh, Hydrocode simulation of the Chicxulub impact event and the production of climatically active gases, J. Geophys. Res. 103 (1998) 28607-28625.

[139] K.O. Pope, Impact dust not the cause of the CretaceousTertiary mass extinction, Geology 30 (2002) 99-102.

[140] D.R. Prothero, The Late Eocene-Oligocene extinctions, Annu. Rev. Earth Planet. Sci. 22 (1994) 145-165.

[141] G. Racki, Frasnian-Fammenian biotic crisis: undervalued tectonic control?, Palaeogeogr. Palaeoclimatol. Palaeoecol. 141 (1998) 177-198.

[142] G. Racki, M.R. House, Foreword (to special issue on Frasnian-Famennian transition), Palaeogeogr. Palaeoclimatol. Palaeoecol. 181 (2002) 1-4.

[143] M.R. Rampino, R.B. Stothers, Flood basalt volcanism during the past 250 million years, Science 241 (1988) 663-668.

[144] G.V.S.P. Rao, K.J.P. Lakshmi, Palaeomagnetism of Deccan traps from the Killari borehole flows, Curr. Sci. 77 (1999) 964-967.

[145] M.I.B. Raposo, M. Ernesto, P.R. Renne, Paleomagnetism and ${ }^{40} \mathrm{Ar} /{ }^{39} \mathrm{Ar}$ dating of the Florianópolis dike swarm, Santa Catarina Island, Brazil, Phys. Earth Planet. Inter. 108 (1998) 275-290.

[146] D.M. Raup, J.J. Sepkoski, Periodicity of Extinctions in the Geologic Past, Proc. Natl. Acad. Sci. Biol. 81 (1984) 801805.

[147] M.K. Reichow, A.D. Saunders, R.V. White, M.S. Pringle, A.I. Al'Mukhamedov, A.I. Medvedev, N.P. Kirda, Ar-40/Ar39 dates from the West Siberian Basin: Siberian flood basalt province doubled, Science 296 (2002) 1846-1849.

[148] P.R. Renne, Flood basalts: bigger and badder, Science 296 (2002) 1812-1813.

[149] P.R. Renne, A.R. Basu, Rapid eruption of the Siberian traps flood basalts at the Permo-Triassic boundary, Science 253 (1991) 176-179.

[150] P.R. Renne, M. Ernesto, I.G. Pacca, R.S. Coe, J.M. Glen, M. Prévot, M. Perrin, The age of Parana flood volcanism, rifting of Gondwanaland, and the Jurassic-Cretaceous boundary, Science 258 (1992) 975-979.

[151] P.R. Renne, Z. Zichao, M.A. Richards, M.T. Black, A. Basu, Synchrony and causal relations between Permian-Triassic boundary crises and Siberian flood volcanism, Science 269 (1995) 1413-1415.

[152] P.R. Renne, K. Deckart, M. Ernesto, G. Féraud, E.M. Piccirillo, Age of the Ponta Grossa dike swarm (Brazil), and implications to Parana flood volcanism, Earth Planet. Sci. Lett. 144 (1996) 199-211.

[153] P.R. Renne, C.C. Swisher, A.L. Deino, D.B. Karner, T. Owens, D.J. DePaolo, Intercalibration of standards, absolute ages and uncertainties in ${ }^{40} \mathrm{Ar} /{ }^{39} \mathrm{Ar}$ dating, Chem. Geol. (Isot. Geosci. Sect.) 145 (1998) 117-152.

[154] P.R. Renne, W.D. Sharp, I.P. Montanez, T.A. Becker, R.A. Zierenberg, Ar-40/Ar-39 dating of Late Permian evaporites, southeastern New Mexico, USA, Earth Planet. Sci. Lett. 193 (2001) 539-547.

[155] P.R. Renne, W.U. Reimold, C. Koeberl, R. Hough, P. Claeys, Critical comment on: I.T. Uysal et al. 'K-Ar evidence 
from illitic clays of a Late Devonian age for the 120-km diameter Woodleigh impact structure, Southern Carnarvon Basin, Western Australia', Earth Planet. Sci. Lett. 201 (1-2) (2002) 247-252.

[156] M.A. Richards, R.A. Duncan, V. Courtillot, Flood basalts and hot spot tracks: plume heads and tails, Science 246 (1989) 103-107.

[157] T.R. Riley, K.B. Knight, Age of pre-break-up Gondwana magmatism, Antarct. Sci. 13 (2) (2001) 99-110.

[158] P. Rochette, E. Tamrat, G. Feraud, R. Pik, V. Courtillot, E. Ketefo, C. Coulon, C. Hofmann, D. Vandamme, G. Yirgu, Magnetostratigraphy and timing of the Oligocene Ethiopian traps, Earth Planet. Sci. Lett. 164 (1998) 497-510.

[159] A.D. Saunders, J. Tarney, A.C. Kerr, R.W. Kent, The formation and fate of large oceanic igneous provinces, Lithos 37 (1996) 81-95.

[160] J.G. Sclater, C. Jaupart, D. Galson, The heat flow through oceanic and continental crust, and the heat loss of the Earth, Rev. Geophys. Sp. Phys. 18 (1980) 269-311.

[161] S. Self, T. Thordarson, L. Keszthelyi, Emplacement of continental flood basalts lava flows, in: J.J. Mahoney, M.F. Coffin (Eds.), Large igneous provinces: continental, oceanic, and planetary flood volcanism, Geophys. Monogr. 100 (1997) 381-410.

[162] J.J. Sepkoski, The taxonomic structure of periodic extinction, in: V.L. Sharpton, P.D. Ward (Eds.), Global Catastrophes in Earth History, Geol. Soc. Am. Spec. Pap. 247 (1990) 33-44.

[163] H.C. Sheth, K. Pande, R. Bhutani, ${ }^{40} \mathrm{Ar} /{ }^{39}$ Ar ages of Bombay trachytes: evidence for a Palaeocene phase of Deccan volcanism, Geophys. Res. Lett. 28 (2001) 3513-3516.

[164] P.N. Shukla, N. Bhandari, A. Das, A.D. Shukla, J.S. Ray, High iridium concentration of alkaline rocks of Deccan and implications to K/T boundary, Proc. Indian Acad. Sci., Earth Planet. Sci. Lett. 110 (2001) 103-110.

[165] P.W. Signor, J.H. Lipps, Sampling bias, gradual extinction patterns, and catastrophes in the fossil record, Geol. Soc. Am. Spec. Pap. 190 (1982) 291-296.

[166] C.W. Sinton, R.A. Duncan, M. Storey, J. Lewis, J.J. Estrada, An oceanic flood basalt province within the Caribbean plate, Earth Planet. Sci. Lett. 155 (1998) 221-235.

[167] N.H. Sleep, Time dependence of mantle plumes: some simple theory, J. Geophys. Res. 97 (1992) 20007-20019.

[168] R.M.H. Smith, P.D. Ward, Pattern of vertebrate extinctions across an event bed at the Permian-Triassic boundary in the Karoo Basin of South Africa, Geology 29 (2001) 1147-1150.

[169] S.M. Stanley, X. Yang, A double mass extinction at the end of the Paleozoic era, Science 266 (1994) 1340-1344.

[170] K. Stewart, S. Turner, S. Kelley, C. Hawkesworth, L. Kirstein, M. Mantovani, 3-D, ${ }^{40} \mathrm{Ar}-{ }^{39} \mathrm{Ar}$ geochronology in the Parana continental flood basalt province, Earth Planet. Sci. Lett. 143 (1996) 95-109.

[171] M. Storey, J.J. Mahoney, A.D. Saunders, R.A. Duncan, S.P. Kelley, M.F. Coffin, Timing of hot spot related volcanism and the breakup of Madagascar and India, Science 267 (1995) 852-855.

[172] M. Storey, et al., Impact and rapid flow of the Iceland plume beneath Greenland at $61 \mathrm{Ma}$ (abstract), Fall Meeting, Amer- ican Geophysical Union, EOS Trans. AGU 77 (Suppl. 1) (1996) F839.

[173] M. Storey, R.A. Duncan, A.K. Pedersen, L.M. Larsen, H.C. Larsen, Ar-40/Ar-39 geochronology of the West Greenland Tertiary volcanic province, Earth Planet. Sci. Lett. 160 (1998) 569-586.

[174] R.B. Stothers, Flood basalts and extinction events, Geophys. Res. Lett. 20 (1993) 1399-1402.

[175] J.A. Tarduno, W.V. Sliter, L. Kroenke, M. Leckie, H. Mayer J.J. Mahoney, R. Musgrave, M. Storey, E.L. Winterer, Rapid formation of Ontong-Java plateau by Aptian mantle plume volcanism, Science 254 (1991) 399-403.

[176] C. Tegner, R.A. Duncan, S. Bernstein, C.K. Brooks, D.K. Bird, M. Storey, ${ }^{40} \mathrm{Ar} /{ }^{39} \mathrm{Ar}$ geochronology of Tertiary mafic intrusions along the East Greenland rifted margin: relation to flood basalts and the Iceland hot spot track, Earth Planet. Sci. Lett. 156 (1998) 75-88.

[177] T.L. Tolan, S.P. Reidel, M.H. Beeson, J.L. Anderson, K.R. Fecht, D.A. Swanson, Revisions to the estimates of the areal extent and volume of the Columbia River Basalt Group, in: S.P. Reidel, P.R. Hooper (Eds.), Volcanism and tectonism in the Columbia River flood-basalt province, Geol. Soc. Am. Spec. Pap. 239 (1989) 1-20.

[178] O.B. Toon, K. Zahnle, D. Morrison, R.P. Turco, C. Covey, Environmental perturbations caused by impacts of asteroids and comets, Rev. Geophys. 35 (1997) 41-78.

[179] Y. Touchard, Trapps d'Éthiopie à $30 \mathrm{Ma}$ : identification de retombées volcaniques à grandes distances et leur impact climatique, PhD thesis, University Aix-Marseille-3, 2002, $268 \mathrm{p}$

[180] Y. Touchard, P. Rochette, M.P. Aubry, A. Michard, Highresolution magnetostratigraphic and biostratigraphic study of Ethiopian traps related products in leg 115 Oligocene sediments, Earth Planet. Sci. Lett. (submitted).

[181] I.A. Ukstins, P.R. Renne, E. Wolfenden, J. Baker, D. Ayalew, M. Menzies, Matching conjugate volcanic rifted margins: ${ }^{40} \mathrm{Ar} /{ }^{39} \mathrm{Ar}$ chrono-stratigraphy of pre- and syn-rift bimodal flood volcanism in Ethiopia and Yemen, Earth Planet. Sci. Lett. 198 (2002) 289-306.

[182] I.T. Uysal, S.D. Golding, A.Y. Glikson, A.J. Mory, M. Glikson, $\mathrm{K}-\mathrm{Ar}$ evidence from illitic clays of a Late Devonian age for the 120-km-diameter Woodleigh impact structure, Southern Carnarvon Basin, Western Australia, Earth Planet. Sci. Lett. 192 (3) (2001) 281-289.

[183] T.R. Venkatesan, K. Pande, K. Gopalan, Did Deccan volcanism pre-date the Cretaceous/Tertiary transition?, Earth Planet. Sci. Lett. 119 (1993) 181-189.

[184] T.R. Venkatesan, K. Pande, Z.G. Ghevariya, Ar-40-Ar-39 ages of Anjar traps, western Deccan Province (India) and its relation to the Cretaceous-Tertiary boundary events, Curr. Sci. 70 (1996) 990-996.

[185] P.R. Vogt, Evidence for global synchronism in mantle plume convection, and possible significance for geology, Nature 240 (1972) 338-342.

[186] T. Waight, J. Baker, B. Willigers, Rb-isotope dilution analyses by MC-ICPMS using $\mathrm{Zr}$ to correct for mass fractionation: towards improved $\mathrm{Rb}-\mathrm{Sr}$ geochronology?, Chem. Geol. 186 (12) (2002) 99-116 
[187] B. Walter, Au Valanginien supérieur, une crise de la faune des bryozoaires : indication d'un important refroidissement dans le Jura, Palaeogeogr. Palaeoclimatol. Palaeoecol. 74 (1989) 255-263.

[188] R.E. Weems, P.E. Olsen, Synthesis and revision of groups within the Newark supergroup, eastern North America, Bull. Geol. Soc. Am. 109 (1997) 195-209.

[189] M. Widdowson, Palaeosurfaces: recognition, reconstruction, and palaeoenvironmental interpretation, Geol. Soc. Lond. Spec. Publ. 120 (1997)

[190] P.B. Wignall, Large igneous provinces and mass extinctions, Earth Sci. Rev. 53 (2001) 1-33.

[191] M. Wilson, Z.M. Lyashkevitch, Magmatism and the geodynamics of rifting of the Prypiat-Dnieper-Donets rift, East European Platform, Tectonophysics 268 (1996) 65-81.

[192] M. Wilson, N. Kusznir, Z.M. Lyashkevich, A.M. Nikishin Late Devonian magmatic activity associated with the PripyatDniepr-Donets rift, Europrobe Georift Conference, Abstract, Vol. 18, Zürich, Switzerland, 16-19 October 1997.

[193] H. Yin, S. Huang, K. Zhang, H.J. Hansen, F. Yang, M. Ding, $\mathrm{X}$. Bie, The effects of volcanism of the Permo-Triassic mass extinction in South China, in: W.C. Sweet, Y. Zunyi, J.M. Dickins, Y. Hongfu (Eds.), Permo-Triassic Events in the Eastern Tethys (stratigraphy, classification, and relations with the western Tethys), in: World Regional Geology, Vol. 2, Cambridge University Press, Cambridge, UK, 1992, p. 181.

[194] J. Zachos, M. Pagani, L. Sloan, E. Thomas, K. Billups, Trends, rhythms, and aberrations in global climate $65 \mathrm{Ma}$ to Present, Science 292 (2001) 686-693.

[195] Z. Zhou, P.R. Renne, R. Mundil, ${ }^{40} \mathrm{Ar} /{ }^{39} \mathrm{Ar}$ dating of PermoTriassic bentonites from the Shangsi section, China, EOS Trans. Am. Geophys. Un. 82 (47) (2001) 1385.

[196] M.F. Zhou, J. Malpas, X.Y. Song, P.T. Robinson, M. Sun, A.K. Kennedy, C.M. Lesher, R.R. Keays, A temporal link between the Emeishan large igneous province (SW China) and the end-Guadalupian mass extinction, Earth Planet. Sci. Lett. 196 (2002) 113-122.

[197] V.V. Zolotukhin, A.I. Al'Mukhamedov, Traps of the Siberian platform, in: J.D. Mahoney (Ed.), Continental Flood Basalts, Kluwer Academic Publishing, Amsterdam, 1988, pp. 273310 . 